\title{
Cationic Cyclopentadienyliron Complex as a Novel and Successful Nucleating Agent on the Crystallization Behavior of the Biodegradable PHB Polymer
}

\author{
Safaa H. El-Taweel ${ }^{1,2, *}$, Arwa O. Al-Ahmadi ${ }^{1}{ }^{(\mathbb{D}}$, Omaima Alhaddad ${ }^{1}$ and Rawda M. Okasha ${ }^{1, *}$ \\ 1 Department of Chemistry, Taibah University, 30002 Al-Madinah Al-Munawarah, Saudi Arabia; \\ rooor.oth@hotmail.com (A.O.A.-A.); alhaddad105@yahoo.com (O.A.) \\ 2 Chemistry Department, Faculty of Science, Cairo University, Orman-Giza, P.O. 12613, Egypt \\ * Correspondence: s_eltaweel@yahoo.com (S.H.E.-T.); rawdao@yahoo.com or rokasha@taibahu.edu.sa (R.M.O.); \\ Tel.: +20-121-031-2095 (S.H.E.-T.); +966-5-300-68276 (R.M.O.)
}

Received: 30 September 2018; Accepted: 15 October 2018; Published: 19 October 2018

\begin{abstract}
Cationic cyclopentadienyliron $\left(\mathrm{CpFe}^{+}\right)$is one of the most fruitful organometallic moieties that has been utilized to mediate the facile synthesis of a massive number of macromolecules. However, the ability of this compound to function as a nucleating agent to improve other macromolecule properties has not been explored. This report scrutinizes the influence of the cationic complex as a novel nucleating agent on the spherulitic morphology, crystal structure, and isothermal and non-isothermal crystallization behavior of the Poly(3-hydroxybutyrate) (PHB) bacterial origin. The incorporation of the $\mathrm{CpFe}^{+}$into the PHB materials caused a significant increase in its spherulitic numbers with a remarkable reduction in the spherulitic sizes. Unlike other nucleating agents, the SEM imageries exhibited a good dispersion without forming agglomerates of the $\mathrm{CpFe}^{+}$moieties in the PHB matrix. Moreover, according to the FTIR analysis, the cationic organoiron complex has a strong interaction with the PHB polymeric chains via the coordination with its ester carbonyl. Yet, the XRD results revealed that this incorporation had no significant effect on the PHB crystalline structure. Though the $\mathrm{CpFe}^{+}$had no effect on the polymer's crystal structure, it accelerated outstandingly the melt crystallization of the PHB. Meanwhile, the crystallization half-times $\left(\mathrm{t}_{0.5}\right)$ of the PHB decreased dramatically with the addition of the $\mathrm{CpFe}^{+}$. The isothermal and non-isothermal crystallization processes were successfully described using the Avrami model and a modified Avrami model, as well as a combination of the Avrami and Ozawa methods. Finally, the effective activation energy of the $\mathrm{PHB} / \mathrm{CpFe}^{+}$nanocomposites was much lower than those of their pure counterparts, which supported the heterogeneous nucleation mechanism with the organometallic moieties, indicating that the $\mathrm{CpFe}^{+}$ is a superior nucleating agent for this class of polymer.
\end{abstract}

Keywords: cationic organoiron complex; bacterial Poly(3-hydroxybutyrate) (PHB); nanocomposites; spherulitic morphology; crystal structure; isothermal and non-isothermal crystallization; thermal stability; FTIR analysis

\section{Introduction}

The development of biopolymers has attracted great interest over the years as a replacement for petroleum polymers. The key feature of this interest arises from the detrimental impact of traditional polymers on the world's ecosystems. As a result, many researchers seek to exploit the synthesis of polymeric materials from renewable resources that will not persist in the environment after disposal [1-4]. 
Successful examples in this field include the synthesis of thermoplastic starch, poly(hydroxyalkanoic acid)s (PHAs), poly(lactic) acid, and their blends or copolymers with other biopolymers [5,6].

Among the poly(hydroxyalkanoic acid)s, polyester of 3-hydroxybutyrate (PHB) is an attractive example of a biodegradable and biocompatible polymer $[7,8]$, which could be accessible via bacteria as intracellular carbon and energy storage compounds and accumulated as granules in the cytoplasm of cells $[9,10]$. This thermoplastic polymer has also been recognized as one of the most promising biopolymers in packaging and biomedical applications [11,12].

A general comparison of biodegradable polymers to traditional classes revealed certain drawbacks that pose challenges to their commercial applications. For example, in the case of PHB, its manufacturability has been limited due to its stiff and brittle character, narrow processing window, and high cost [13-15]. Another obstacle is the slow crystallization rate of PHB [14,15], when processed under conventional injection, molding, and/or extrusion methods, which have resulted in poor dimensional stability and low tackiness.

Several strategies have been reported to overcome some of the aforementioned disadvantages [16,17]. One of these strategies involves the insertion of nucleating agents into the PHB matrix in order to manipulate its crystallization rate, which makes it competitive with synthetic thermoplastic polymers. Various reports have revealed that the addition of nucleating agents to PHB has resulted in a significant improvement in thermal, mechanical, and other physical properties. Examples of these nucleating agents have included the following: $\mathrm{NH}_{4} \mathrm{Cl}$ [18], melamine [19], boron nitride [20,21], talc [22,23], cyanuric acid [24], cyclodextrin [25], lignin [26], and thermally reduced graphene (TRG) [27]. Recent examples have incorporated nanofillers, such as multi-walled carbon nanotubes [28,29], $\mathrm{TiO}_{2}$, and $\mathrm{ZnO}$ nanoparticles [30], graphite nanosheets [31], and $\mathrm{WS}_{2}$ inorganic nanotubes [32].

Despite the prevalence of previous studies that have explored a tremendous number of nucleating agents, this topic continues to be researched in order to overcome the drawbacks that have been associated with such nucleating agents [33-43]. For instance, some of the nucleating agents face an agglomeration issue inside the polymer matrix, which is attributed to the variance in surface energy [35]. This usually occurs with slow solvent evaporation or via the interface of the inorganic filler with the organic polymeric matrix. As a solution, researchers have made several attempts to modify the polymer matrix-filler interface through the incorporation of coupling agents, such as silane, onto the filler surface, which can enhance the interfacial bonding strength of the composites and improved its dispersity [34,44,45]. Meanwhile, examining new classes of nucleating agents remains one of the most successful strategies.

Over the past two decades, our work has been focused on utilizing the cationic cyclopentadienyl iron moieties in designing novel classes of monomeric and polymeric materials [46-49]. The intense electron withdrawing ability of the positively charged iron center facilitates nucleophilic substitution and addition reactions on the arene rings and allows for the production of these macromolecules under mild conditions. Furthermore, the iron complex demonstrates several advantages over other $\pi$-coordinated metallic moieties due to its chemical versatility, stability, low cost, and low toxicity [50-53].

This work presents the first example of exploring the effect of the $\mathrm{CpFe}^{+}$complex as a novel nucleating agent on the isothermal and non-isothermal crystallization behavior of PHB using Differential Scanning Calorimetry (DSC) and polarized optical microscopy (POM). The crystallization kinetics and the activation energy have also been analyzed using several models, such as Avrami, Ozawa, a combination Avrami and Ozawa model, and the differential isoconversional method of Friedman.

\section{Results and Discussion}

\subsection{Polarized Optical Microscopy}

Figure 1 represents the polarized optical micrographs of the $\mathrm{PHB}$ and $\mathrm{PHB} / \mathrm{CpFe}^{+}$ nanocomposites at the isothermal crystallization condition, $100{ }^{\circ} \mathrm{C}$. The obtained results revealed 
that the size of the PHB's spherulite was found to be as large as $1 \mathrm{~mm}$, while the spherulite number was extremely small. This behavior could be attributed to the exceptional purity of the PHB that was prepared via bacterial origin [14]. It is also illustrated in Figure 1 that the $\mathrm{PHB}$ and $\mathrm{PHB} / \mathrm{CpFe}^{+}$ nanocomposites displayed a Maltese cross section with regular extinction rings. The presence of the cationic cyclopentadienyliron $\left(\mathrm{CpFe}^{+}\right)$moieties led to the production of smaller spherulites than that existing in the pure $\mathrm{PHB}$, where the $\mathrm{CpFe}^{+}$nanoparticles were trapped in the center of the spherulites in the form of brown colored dots. Also, the $\mathrm{CpFe}^{+}$particles were well distributed in the PHB matrix, which is clearly seen in the SEM images in Figure 2. Moreover, increasing the amount of the CpFe ${ }^{+}$ correspondingly increased the number of small spherulites. These results categorized the $\mathrm{CpFe}^{+}$as one of the most highly efficient nucleating agents of PHB.
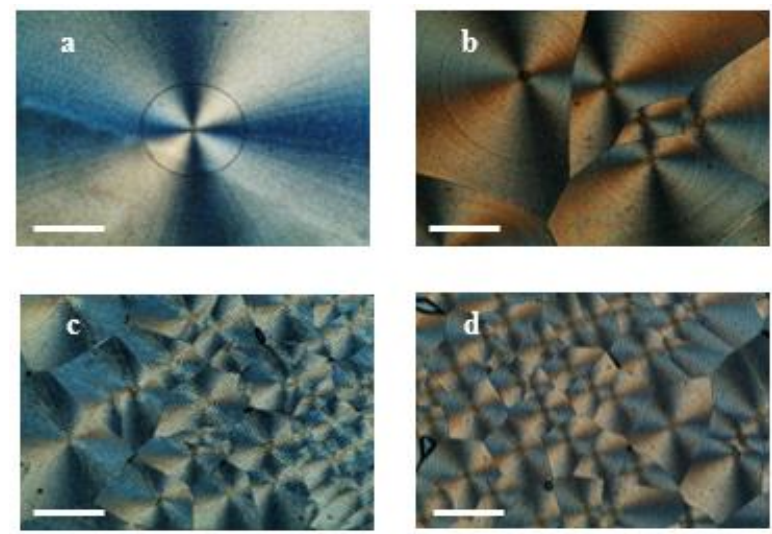

Figure 1. Polarized light optical micrographs of Poly(3-hydroxybutyrate) (PHB) spherulites of the pure PHB and PHB/CpFe ${ }^{+}$nanocomposites with ratios of (a) 100:0, (b) 99.5:0.5, (c) 99:1, and (d) 97:3, respectively, after the isothermal crystallization at $100{ }^{\circ} \mathrm{C}$ scale bar $200 \mu \mathrm{m}$.

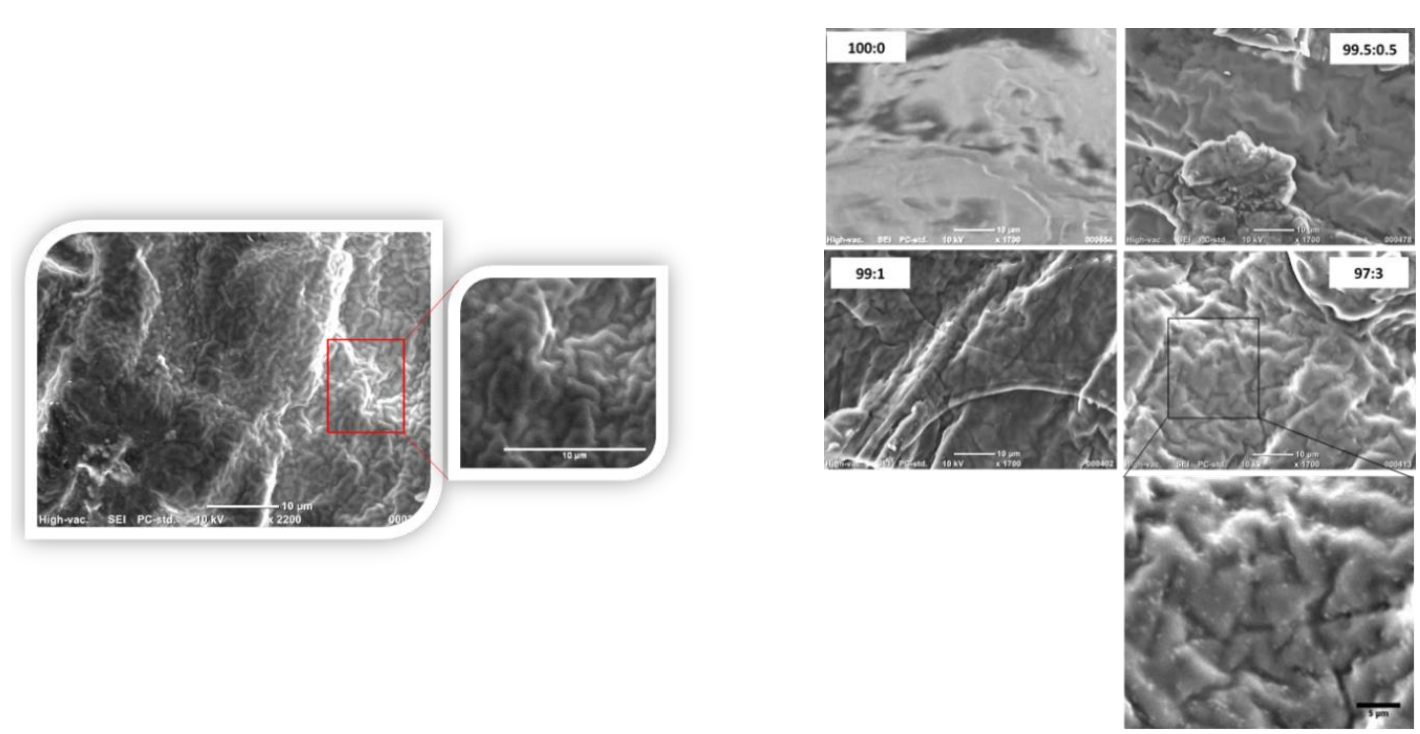

Figure 2. SEM micrographs of the pure $\mathrm{PHB}$ and $\mathrm{PHB} / \mathrm{CpFe}^{+}$nanocomposites with $0.5 \%, 1 \%$, and $3 \%$ of the $\mathrm{CpFe}^{+}$moieties (right); zoomed-in image of the $97: 3 \%$ of $\mathrm{PHB} / \mathrm{CpFe}^{+}$(left) that shows the helix structure with $\times 2200$, scale bar $10 \mu \mathrm{m}$.

\subsection{Scanning Electron Microscope (SEM)}

The morphologies of the $\mathrm{PHB}$ and $\mathrm{PHB} / \mathrm{CpFe}^{+}$nanocomposites were examined using scanning electron microscope (SEM). Figure 2 elucidates the smooth, fractured surface of the pure PHB. Upon the combination of the cationic iron moieties with the $\mathrm{PHB}$, the images revealed a remarkable distribution of the $\mathrm{CpFe}^{+}$species without forming agglomerates in the polymer matrix. This behavior remained 
incessant while increasing the nucleating agent ratio. Additionally, the incorporation of the iron moieties into the polymer matrix triggered the formation of the helical structures of the polymer chains during the crystallization process, which can be observed in some of the SEM images [54-56].

\subsection{FTIR Analysis}

The FTIR spectra of the $\mathrm{CpFe}{ }^{+}$moiety, pure $\mathrm{PHB}$, and $\mathrm{PHB} / \mathrm{CpFe}^{+}$nanocomposites with a 99:1\%, respectively, are illustrated in Figure 3. It is well known that the amorphous melt of the pure PHB can be crystalized during the cooling process, forming an antiparallel helical structure due to the formation of hydrogen bonds within the polymer matrix [55]. Meanwhile, preparing the blend sheets required the cast film samples to be molten between a hot melt press at $200{ }^{\circ} \mathrm{C}$ for $2 \mathrm{~min}$. This process allowed for the decomplexation of the arene ring of the cationic iron moieties [47-49], which increased the possibility of forming a dipole interaction within the helical structure through the chlorine terminal atoms of the arene rings, as seen in Scheme 1. The decoordination of the arene ring could be confirmed via the FTIR spectra. For instance, the pure cationic cylopentadienyliron complex exhibited an out of plan bending peak, corresponding to the complexed arene $\mathrm{C}-\mathrm{H}$ at $816 \mathrm{~cm}^{-1}$, while their stretching bands were observed at 469 and $553 \mathrm{~cm}^{-1}$. These peaks were shifted to a higher frequency, 1055 and $1410 \mathrm{~cm}^{-1}$, after the decoordination process and the blending with the PHB polymer; in addition, the spectrum exhibited a disappearance of the complexed arene $\mathrm{C}-\mathrm{H}$ band at $3097 \mathrm{~cm}^{-1}$. On the other hand, the cyclopentadienyliron moieties became more susceptible to the coordination with the ester carbonyl of the polymer, as seen in Scheme 1. This finding has been verified via the obtained spectra. As can be seen from Figure 3, the characteristic peak at $1719 \mathrm{~cm}^{-1}$ in the pure PHB spectrum was assigned to the ester carbonyl group within the polymer matrix. Upon blending the polymeric materials with the $\mathrm{CpFe}^{+}$complex, a decrease in the carbonyl stretching frequency was observed while maintaining its value, which confirmed the formation of a chelating complexation to the cationic iron moieties. Furthermore, the frequencies of the complexed cyclopentadienyl $\mathrm{C}-\mathrm{H}$ stretching band and the $\mathrm{CH}_{3}$ bands of the PHB chains, in the range of 2901-2987 $\mathrm{cm}^{-1}$, were increased after the blending process with the preservation of their values, which supported the complexation behavior of the iron centers towards the PHB matrix

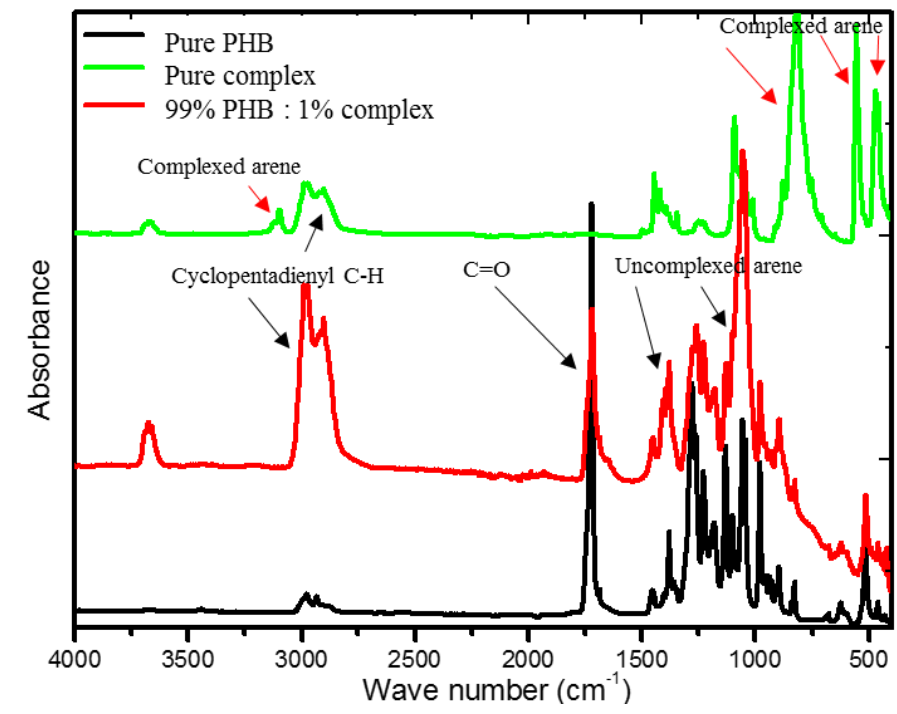

Figure 3. FTIR spectra of the $\mathrm{CpFe}^{+}$complex, pure $\mathrm{PHB}$, and $\mathrm{PHB} / \mathrm{CpFe}^{+}$nanocomposites. 


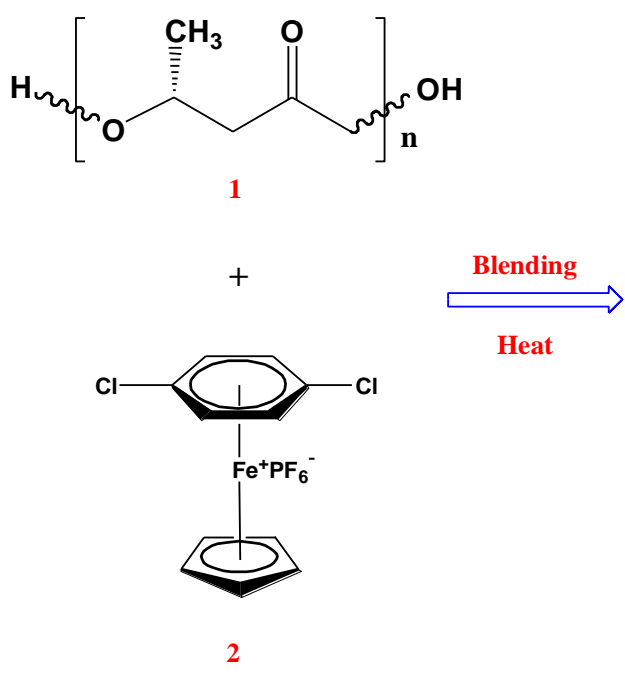

2

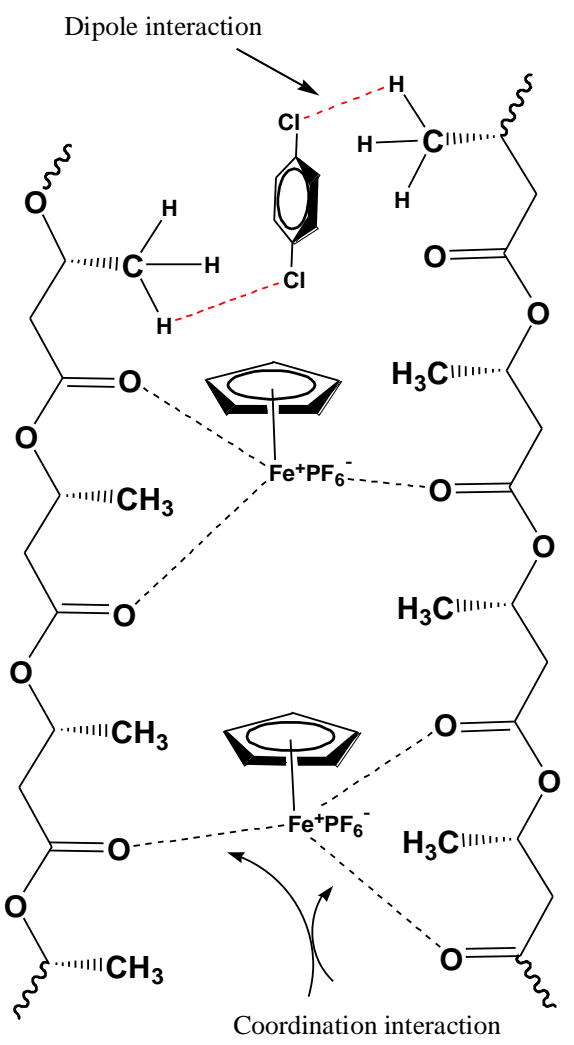

Scheme 1. Proposed mechanism of the $\mathrm{PHB} / \mathrm{CpFe}^{+}$interaction.

\subsection{X-ray Results}

Figure 4 shows the X-ray diffractograms of the pure $\mathrm{PHB}, \mathrm{CpFe}{ }^{+}$, and the $\mathrm{PHB} / \mathrm{CpFe}^{+}$ nanocomposites. The characteristic Bragg reflection peaks of the $\mathrm{CpFe}^{+}$complex can be observed at $2 \theta=19.77,20.08$, and 21.48, which is indexed on the bases of the face centered cubic (FCC) structure of iron and found to be identical to those reported for the standard iron metal. The average crystal size of the $\mathrm{CpFe}^{+}$was calculated, according to the Scherrer equation, and found to be around $42 \mathrm{~nm}$. However, blending this organometallic complex with the PHB, followed by the thermal processing of the prepared sheets, enhanced the tendency of the iron center to coordinate with the ester carbonyl of the polymer as described previously and illustrated in Scheme 1. This coordination behavior of the $\mathrm{CpFe}^{+}$was one of major factors that facilitated the excellent distribution of the metallic centers within the polymer matrix. Furthermore, the coordination process led to the disappearance of the diffraction peaks of the $\mathrm{CpFe}^{+}$moiety at the (021) area. On the other hand, the metallic moieties exhibited a crystal matching with the polymeric materials that was evidenced by the perfect alignment of the diffraction peaks, which can be observed through the growth of its peaks at the (101) and (110) areas. It is also noticeable that the diffraction peaks of the PHB became sharper and narrower than the pure PHB ones with the increasing of the percentage of the iron complex, which is an indication of the increasing crystallinity of the modified polymer. Utilizing the Scherrer equation, the pure PHB exhibited a crystal size of $32.7 \mathrm{~nm}$, while the $\mathrm{PHB} / \mathrm{CpFe}^{+}$nanocomposites displayed crystal sizes of $35.5,36.8$, and $37.2 \mathrm{~nm}$ for $0.5 \%, 1 \%$, and $3 \%$ of the $\mathrm{CpFe}+$ nanocomposites. In spite of the fact that the diffraction peaks of the modified polymeric materials retained their values, which suggested that the presence of the metallic moieties did not alter the structure of the polymer, increasing the ratio of the iron moieties reduced the intermolecular interactions between the $\mathrm{C}=\mathrm{O}$ group and the $\mathrm{CH}_{3}$ group of the PHB due to the formation of a coordination interaction with the $\mathrm{CpFe}^{+}$complex. This behavior resulted in the increase of the intensity and the narrowing of the (110) peak area with a value of $2 \theta$ $\left(16.88^{\circ}\right)$ (marked with asterisk). In order to verify the consistency of this performance, an extra ratio of the $\mathrm{CpFe}^{+}(10 \%)$ was blended with the PHB. Figure 4 (bottom) elucidates a comparison of the XRD 
patterns of the PHB blended with 1\%, 3\%, and 10\% of the CpFe+ nanocomposites, which substantiates the previous findings.
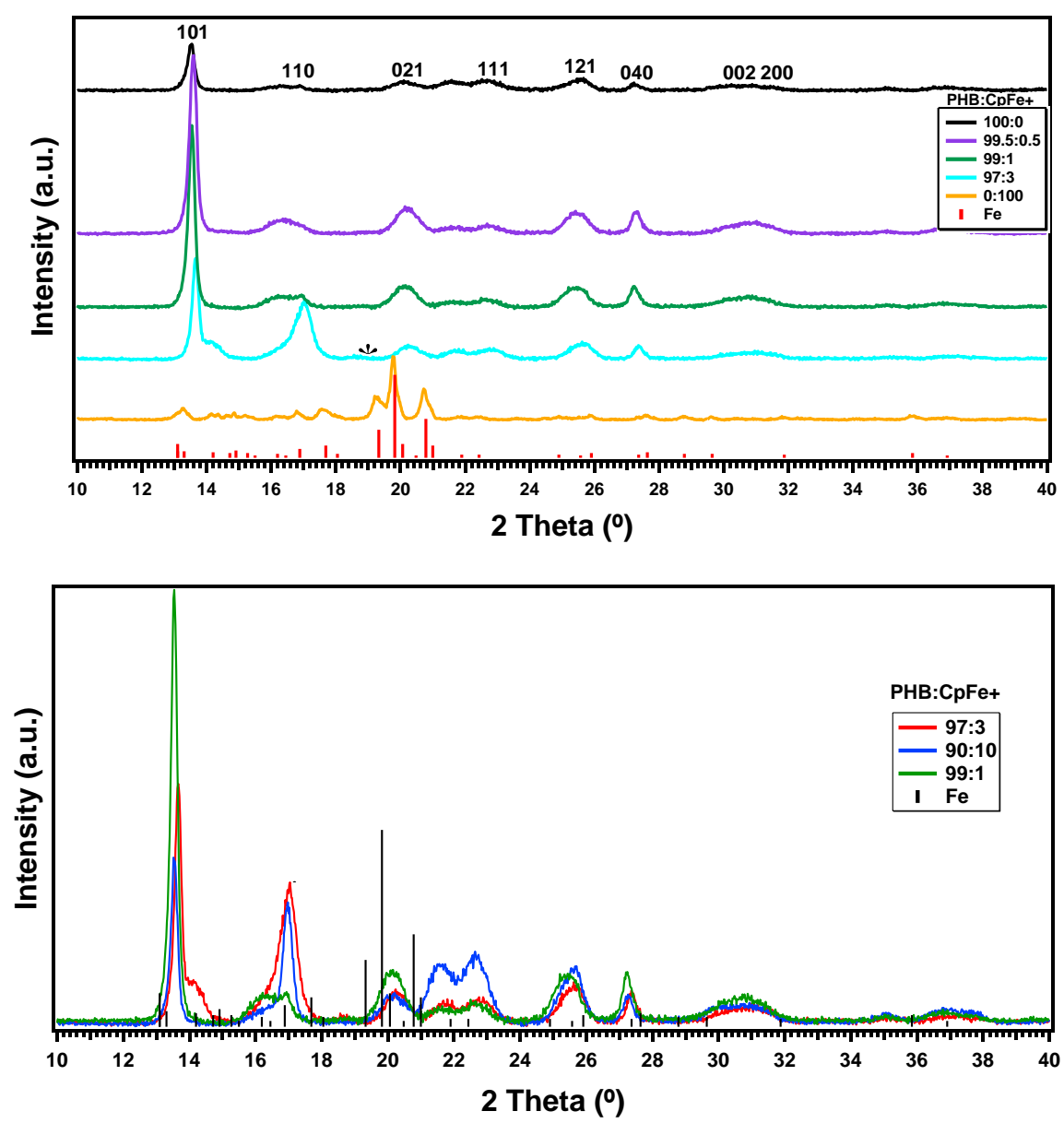

Figure 4. XRD pattern of pure $\mathrm{PHB}$ and $\mathrm{PHB} / \mathrm{CpFe}^{+}$nanocomposites with ratios of 100:0, 99.5:0.5, 99:1, 97:3 respectively (top). XRD pattern of a higher ratio of $\mathrm{CpFe}^{+} 1 \%, 3 \%$, and $10 \%$ (bottom).

\subsection{Thermal Properties}

The Differential Scanning Calorimetry (DSC) cooling curves of the PHB and its nanocomposites are presented in Figure 5 and exhibited an exothermic peak corresponding to the PHB crystallization. It is well known that a higher value of the crystallization temperature, $T_{c}$, is an indication of a faster crystallization rate. The values of the crystallization temperatures $\left(\mathrm{T}_{\mathrm{c}}\right)$ and the crystallization enthalpy $\left(\Delta \mathrm{H}_{\mathrm{c}}\right)$ are reported in Table 1.
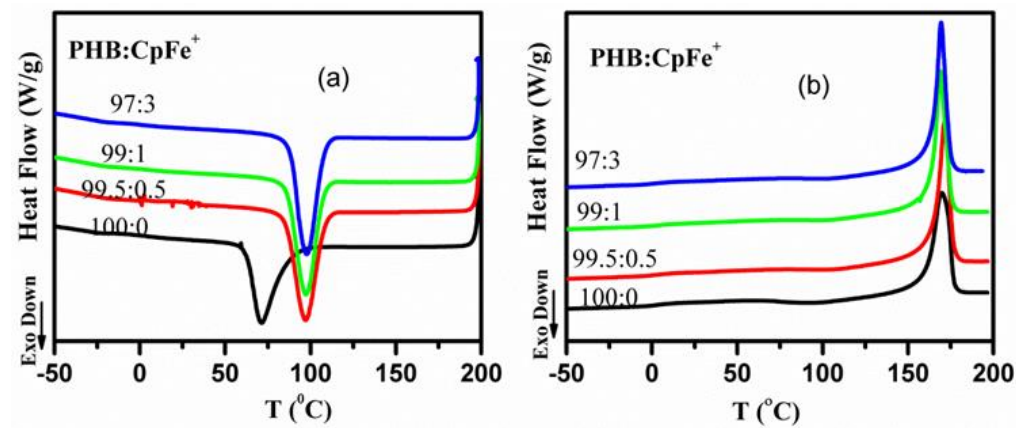

Figure 5. DSC curves of the pure $\mathrm{PHB}$ and $\mathrm{PHB} / \mathrm{CpFe}^{+}$nanocomposites; (a) cooling curves from the melt at a cooling rate $20^{\circ} \mathrm{C} / \mathrm{min},(\mathbf{b})$ second heating curves with a heating rate $20^{\circ} \mathrm{C} / \mathrm{min}$. 
Table 1. Thermal parameters of the pure PHB and PHB/CpFe ${ }^{+}$nanocomposites from DSC (cool and second heating) curves.

\begin{tabular}{|c|c|c|c|c|c|c|c|c|c|c|c|c|}
\hline \multirow{2}{*}{\multicolumn{2}{|c|}{$\begin{array}{l}\text { Name of PHB } \\
\text { Samples }\end{array}$}} & $T_{c} \pm 1$ & Width & $\Delta H_{c} \pm 5$ & $T_{g} \pm 2$ & $\Delta C_{p}$ & $T_{c c} \pm 1$ & $\Delta H_{c c} \pm 5$ & $T_{m} \pm 1$ & width & $\left(\Delta H_{m}-\Delta H_{c c}\right) \pm 5$ & $\chi_{c}$ \\
\hline & & ${ }^{\circ} \mathrm{C}$ & ${ }^{\circ} \mathrm{C}$ & $\mathrm{J} / \mathrm{g}$ & ${ }^{\circ} \mathrm{C}$ & $\mathrm{J} / \mathrm{g}^{\circ} \mathrm{C}$ & ${ }^{\circ} \mathrm{C}$ & $\mathrm{J} / \mathrm{g}$ & ${ }^{\circ} \mathrm{C}$ & ${ }^{\circ} \mathrm{C}$ & $\mathrm{J} / \mathrm{g}$ & $\%$ \\
\hline \multirow{4}{*}{ 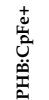 } & 100:0 & 71 & & 59 & 3 & 0.21 & 95 & 8 & 170 & & 72 & 50 \\
\hline & 99.5:0.5 & 97 & 13 & 72 & 2 & 0.16 & 105 & 4 & 170 & 7 & 87 & 60 \\
\hline & $99: 1$ & 97 & 13 & 72 & 2 & 0.17 & 104 & 7 & 169 & 7 & 86 & 60 \\
\hline & 97:3 & 97 & 12 & 73 & 2 & 0.16 & 105 & 4 & 169 & 6 & 87 & 61 \\
\hline
\end{tabular}

The composition of the PHB nanocomposites manipulates the position and shape of the crystallization peak. The presence of the cationic iron $\left(\mathrm{CpFe}^{+}\right)$complexes in the PHB matrix resulted in a shift of the crystallization peaks to a higher temperature, Figure $5 \mathrm{a}$, by $26{ }^{\circ} \mathrm{C}$ for all the PHB nanocomposites. The crystallization peaks of all the PHB nanocomposites maintained their values upon the addition of different ratios of $\mathrm{CpFe}^{+}$complexes. These results could be attributed to the presence of the strong interaction between the organoiron centers $\left(\mathrm{CpFe}^{+}\right)$and the PHB matrix. As can be seen in Figure 5, the appearance of the crystallization peaks of the PHB nanocomposites became sharper and narrower compared with those of the pure $\mathrm{PHB}$, which demonstrated that the $\mathrm{CpFe}^{+}$ acts as an efficient nucleating agent and suggested that the PHB crystallization occurs through a heterogeneous nucleating mechanism [18-32]. Therefore, the values of the $\Delta \mathrm{H}_{\mathrm{c}}$ for all the PHB nanocomposites were higher than those of the pure PHB. Figure $5 b$ presents the DSC heating curves of the PHB and its nanocomposites, while the values of their glass transition temperature $\left(\mathrm{T}_{\mathrm{g}}\right)$, cold crystallization temperature $\left(\mathrm{T}_{\mathrm{CC}}\right)$, and melting temperature $\left(\mathrm{T}_{\mathrm{m}}\right)$ are listed in Table 1 . The obtained results revealed that the values of the glass transition temperatures of the $\mathrm{PHB}$ and its $\mathrm{PHB} / \mathrm{CpFe}{ }^{+}$ nanocomposites were around $2{ }^{\circ} \mathrm{C}$, which was independent of the PHB composition.

It has been established that the heat capacity of the glass transition temperature of amorphous polymers is much higher than those of crystalline ones. Thus, the values of the heat capacities for the PHB in its nanocomposites are lower than those of the pure PHB. Less intense broad exothermic cold crystallization peaks were detected for the nanocomposites during the second heating scan, as shown in Figure $5 \mathrm{~b}$ and Table 1 . These results revealed that the $\mathrm{CpFe}^{+}$in the PHB nanocomposites prompted almost complete PHB crystallization during a cooling scan with $20 \mathrm{~K} / \mathrm{min}$. Meanwhile, above $150{ }^{\circ} \mathrm{C}$, endothermic melting peaks were detected in the second heating scans, as shown in Figure $5 \mathrm{~b}$. The pure PHB and the PHB nanocomposites had similar values with respect to melting temperatures. These results indicated that the $\mathrm{CpFe}^{+}$did not have a significant effect on the crystal structure of the $\mathrm{PHB}$, which was in a good agreement with the XRD results, as shown in Figure 4. A similar trend was reported for the PHB with other nucleating agents [20,26,32,57]. It is worth mentioning that the width of the half height of the melting peak became narrower in comparison to the PHB. The degree of crystallinity was calculated from Equation (1) and reported in Table 1. In conclusion, the DSC results confirmed that the $\mathrm{CpFe}^{+}$moieties had a significant increase in the degree of crystallinity, which suggests that the $\mathrm{CpFe}^{+}$is an efficient nucleating agent for the PHB in PHB nanocomposites, as shown in Table 1.

$$
\mathrm{X}_{c}=\frac{\Delta H_{m}-\Delta H_{c c}}{\Delta H_{m}^{\circ} \times w}
$$

\subsection{Isothermal Crystallization Kinetics}

The isothermal crystallization behavior of the pure PHB and its nanocomposites were investigated by rapidly cooling the melt $\left(70^{\circ} \mathrm{C} / \mathrm{min}\right)$ to the selected crystallization temperature, ranging from $90^{\circ}$ to $128^{\circ} \mathrm{C}$. The exothermic crystallization peaks were recorded as a function of the crystallization time. It is crucial to note that the crystallization peaks were broader at higher crystallization temperatures $(\mathrm{Tc})$, indicating a lower crystallization rate. Figure 6 represents the relative crystallinity $(X(t))$ as a function of the crystallization time $(t / \mathrm{min})$ at $120^{\circ} \mathrm{C}$, the selected crystallization temperature. $\mathrm{X}(\mathrm{t})$ was 
estimated by the analysis of the heat flow of the isothermal crystallization peaks with time, $t$, with the following Equation (2):

$$
X(t)=\frac{\int_{0}^{t} \frac{\partial H}{\partial t} d t}{\int_{0}^{\infty} \frac{\partial H}{\partial t} d t}
$$
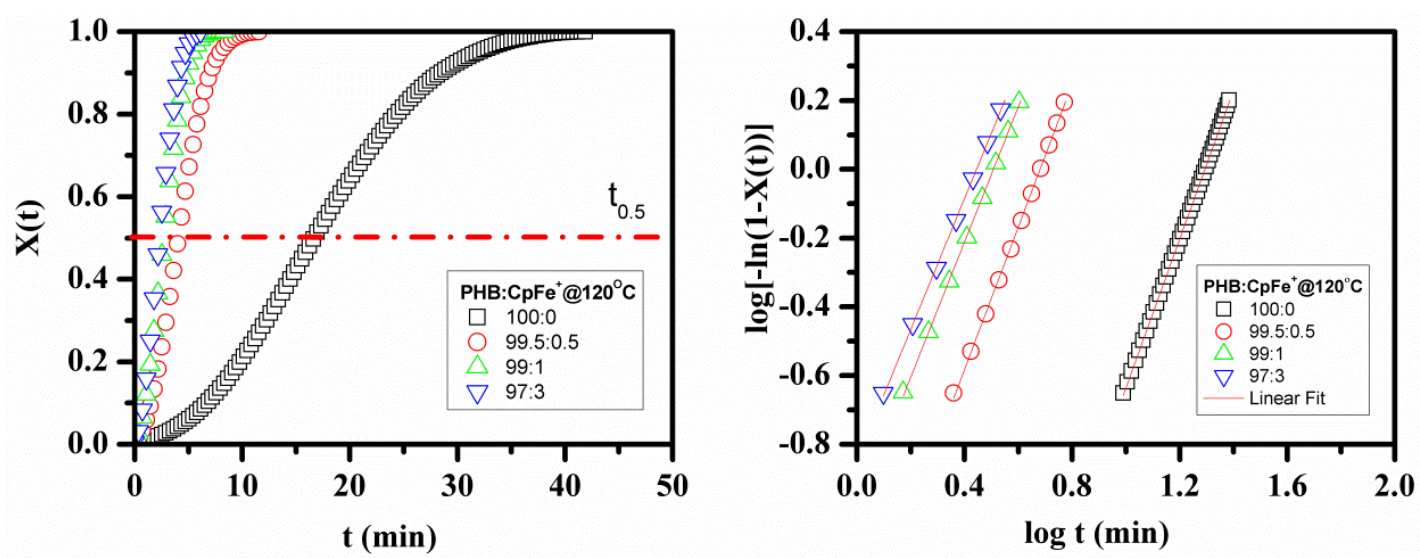

Figure 6. Relative crystallinity $(X(t))$ (right) and its corresponding typical Avrami plot (left) in the isothermal crystallization process for the pure $\mathrm{PHB}$ and $\mathrm{PHB} / \mathrm{CpFe}^{+}$nanocomposites.

The numerator represents the integrated heat flow generated until time $t$, and the denominator is the total heat flow produced in the isothermal crystallization until $t=\infty$. It can be detected that in the $X(t)$ range, between 0.2 and 0.8 , the curves are straight. The isothermal crystallization kinetics of the PHB and its nanocomposites were analyzed based on the Avrami Equation, Equation (3):

$$
X(t)=1-\exp \left(-k t^{n}\right)
$$

The plot of $(\log (-\ln (1-X(t)))$ as a function of $\log (t)$, derived from Equation (3), creates a linear line with the intercept and slope known as $\log \mathrm{k}$ and $\mathrm{n}$, respectively. $\mathrm{n}$ is the Avrami exponent, $\mathrm{k}$ is the overall crystallization kinetic rate constant, and $\mathrm{t}$ is the time of crystallization process. The values of $\mathrm{k}$ and $\mathrm{n}$ depend on the nucleation mechanism and the growth geometry. From Figure 6, it can be concluded that Avrami model, Equation (3), was applicable for describing the isothermal behavior of the PHB nanocomposites.

The crystallization parameters, $k, n$, and $t_{0.5}$, are all reported in Table 2. $t_{0.5}$ is defined as the time at which the relative crystallinity is $50 \%$. As seen in Table $2, t_{0.5}$ decreased with the decrease of the crystallization temperature and increased the percentage of the $\mathrm{CpFe}^{+}$in the $\mathrm{PHB} /$ nanocomposites, which is a required behavior for processing the polymer materials. These results indicated that the rate of the PHB crystallization process is faster when the super cooling temperature is higher within the selected crystallization temperature range. At the given crystallization temperature, $120{ }^{\circ} \mathrm{C}$, the $t_{0.5}$ of the PHB crystallization process in the PHB nanocomposites was much lower than that of the pure analogues, while all the curves of the isothermal crystallization kinetics were almost parallel with each other, as shown in Figure 6. This revealed that the crystallization mechanism of the PHB in its nanocomposites was the same, where their $n$ values were almost constant and approximately equal to 2 . The value of $n$ can be attributed to the presence of thermal crystallization during the crystallization process [58]. Another possible explanation reported in the literature [59] is that the PHB crystals can either develop sporadically as rods or instantaneously as disks. The rate constant, $k$, which is related to both the nucleation and the growth processes, increased with the decrease in the crystallization temperature and the increase of the ratio of the $\mathrm{CpFe}{ }^{+}$complex. For instance, at $120^{\circ} \mathrm{C}$, the crystallization rate of the PHB with the incorporation of $3 \%$ of the $\mathrm{CpFe}^{+}$moieties was found to be 
$87 \%$ faster than that of its pure analogue. These results verify the hypothesis that $\mathrm{CpFe}^{+}$is a superior nucleating agent for this type of polymer.

Table 2. Isothermal crystallization kinetics parameters of the pure $\mathrm{PHB}$ and $\mathrm{PHB} / \mathrm{CpFe}^{+}$nanocomposites based on the Avrami model.

\begin{tabular}{cccccccc}
\hline \multirow{2}{*}{ Name of PHB Samples } & $\mathbf{T}_{\mathbf{c}}$ & $\mathbf{n}$ & $\mathbf{l o g k}$ & $\mathbf{k} \times \mathbf{1 0}^{-\mathbf{2}}$ & $\boldsymbol{R}^{2}$ & $\boldsymbol{t}_{\mathbf{0 . 5}}$ & $\boldsymbol{t}_{\mathbf{0 . 9 9}}$ \\
\cline { 2 - 8 } & ${ }^{\circ} \mathbf{C}$ & & & $\mathbf{m i n}^{-\mathbf{1}}$ & & $\mathbf{M i n}$ & $\mathbf{M i n}$ \\
\hline & 90 & 3 & -0.23 & 59.19 & 1 & 1.07 & 2.1 \\
& 94 & 2 & -0.24 & 58.2 & 1 & 1.08 & 2.52 \\
PHB:CpFe+ & 100 & 2 & -0.62 & 24.01 & 1 & 1.71 & 4.05 \\
$\mathbf{( 1 0 0 : 0 )}$ & 118 & 2 & -2.45 & 0.35 & 1 & 11.5 & 29 \\
& 120 & 2 & -2.80 & 0.16 & 1 & 16.7 & 37.2 \\
& 122 & 2 & -2.80 & 0.16 & 1 & 18.6 & 37.7 \\
& 124 & 2 & -3.13 & 0.055 & 1 & 19.2 & 39.3 \\
\hline \multirow{2}{*}{$99.5: 0.5$} & 120 & 2 & -1.41 & 3.88 & 1 & 4.05 & 9.63 \\
& 124 & 2 & -2.29 & 0.52 & 1 & 9.75 & 21.4 \\
& 128 & 2 & -2.98 & 0.1 & 1 & 18.1 & 38.3 \\
\hline \multirow{3}{*9:1}{} & 120 & 2 & -0.99 & 10.06 & 1 & 2.69 & 6.58 \\
& 124 & 2 & -1.63 & 2.33 & 1 & 5.43 & 13.3 \\
& 128 & 2 & -2.53 & 0.29 & 1 & 12.7 & 29 \\
\hline \multirow{2}{*}{$97: 3$} & 120 & 2 & -0.85 & 14.23 & 1 & 2.31 & 5.53 \\
& 124 & 2 & -1.62 & 2.37 & 1 & 5.4 & 13.2 \\
& 128 & 2 & -2.68 & 0.21 & 1 & 13 & 28.2 \\
\hline
\end{tabular}

\subsection{Non-Isothermal Crystallization Kinetics}

In the polymer processing techniques, the temperature changes continuously. Therefore, investigating the crystallization kinetics under non-isothermal conditions was essential. In general, the exothermic crystallization peak becomes broader and shifts to lower temperatures with the increasing of the cooling rate of all the PHB samples. The dependence of the crystallization temperature (Tc) on the cooling rate for the PHB/nanocomposites is shown in Figure 7.

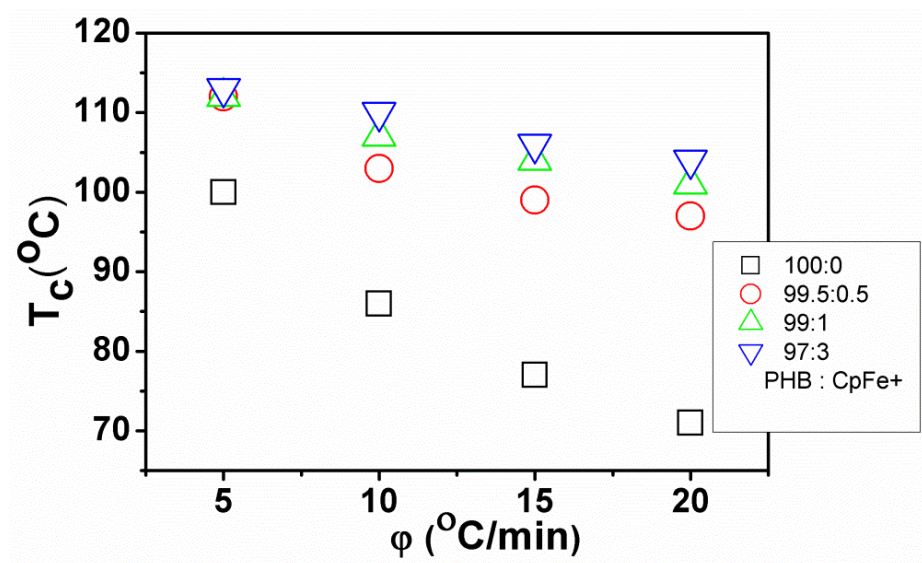

Figure 7. A maximum crystallization temperature as a function of a cooling rate for the non-isothermally crystallized pure $\mathrm{PHB}$ and $\mathrm{PHB} / \mathrm{CpFe}^{+}$nanocomposites.

The attained data disclosed that the crystallization temperature of the PHB in its nanocomposites was higher than those of the pure counterparts for all the studied cooling rates. These results indicated that the enhancement of the crystallization temperature arises from the presence of the $\mathrm{CpFe}^{+}$moieties. 
The relative crystallinity $\mathrm{X}(\mathrm{T})$ was evaluated from the DSC experimental data in Figure 8 by applying Equation (4), as follows:

$$
X(T)=\frac{\int_{T_{0}}^{\mathrm{T}}\left(\frac{\partial \mathrm{H}}{\partial \mathrm{t}}\right) \partial \mathrm{t}}{\int_{\mathrm{T}_{0}}^{\mathrm{T}_{\infty}}\left(\frac{\partial \mathrm{H}}{\partial \mathrm{t}}\right) \partial \mathrm{t}}
$$

The $\mathrm{T}_{0}$ and $\mathrm{T}_{\infty}$ are the onset and the end crystallization temperature, respectively, and the $\partial \mathrm{H}$ is the enthalpy of the process while the temperature is converted into the time scale, using Equation (5) as follows:

$$
\mathrm{t}=\frac{\left|\mathrm{T}-\mathrm{T}_{0}\right|}{\varphi}
$$

The $\mathrm{T}$ is the temperature at the crystallization time, and the $\varphi$ is the cooling rate. The relative crystallinity $(X(t))$ versus the time curves is plotted in Figure 8 where all the curves exhibited the same sigmoidal shape and are shifted to a shorter time with increasing the cooling rates.
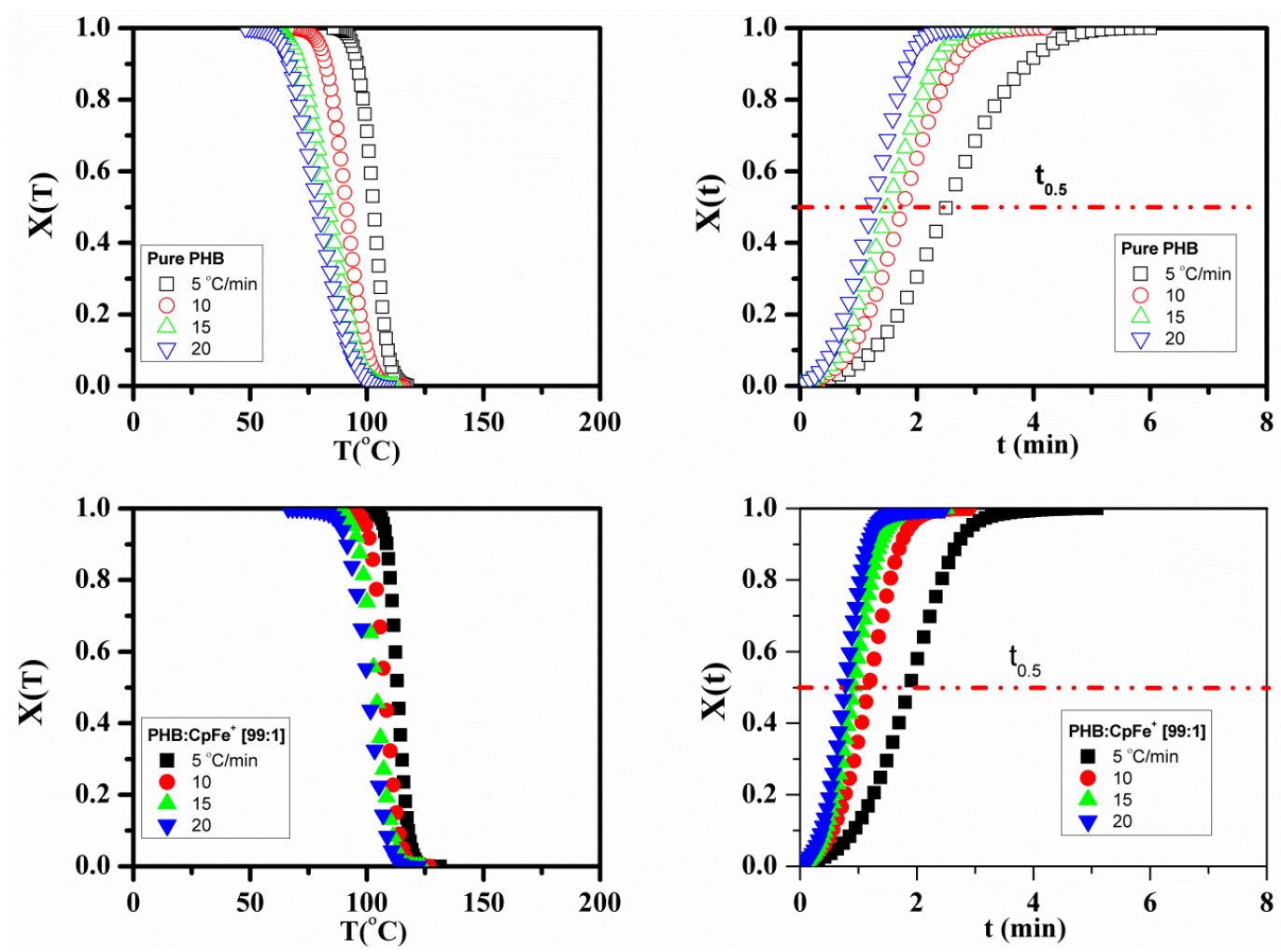

Figure 8. Relative crystallinity as a function of crystallization temperatures and time in the non-isothermal crystallization process for the pure $\mathrm{PHB}$ and $\mathrm{PHB} / \mathrm{CpFe}^{+}$nanocomposites at various cooling rates.

The Avrami model [60], the Ozawa model [61], and the combination of the Avrami and Ozawa models (the MO approach) are most frequently used to analyze the non-isothermal experimental crystallization data [62]. Regarding the cooling rate $(\varphi)$, Jeziorny stated that the value of $\mathrm{k}_{t}$ should be effectively corrected [63], and it can be calculated by Equation (6), as follows:

$$
\log \mathrm{k}_{\mathrm{c}}=\frac{\log \left(\mathrm{k}_{\mathrm{t}}\right)}{\varphi}
$$

Figure 9 displays plots of $\log (-\ln (1-\mathrm{X}(\mathrm{t})))$ versus $\log (\mathrm{t})$. The non-isothermal parameters, crystallization rate constant $\left(\mathrm{k}_{\mathrm{t}}\right)$, and Avrami exponent $(\mathrm{n})$ were estimated by inserting the experimental data of the $X(t)$ to be in the range of 0.2-0.8, using Equation (3), as listed in Table 3. The Avrami exponent 
values, $n$, for the non-isothermal crystallization process were found to be approximately 3 , which was higher than those of the isothermal crystallization for both the pure PHB and PHB nanocomposites.
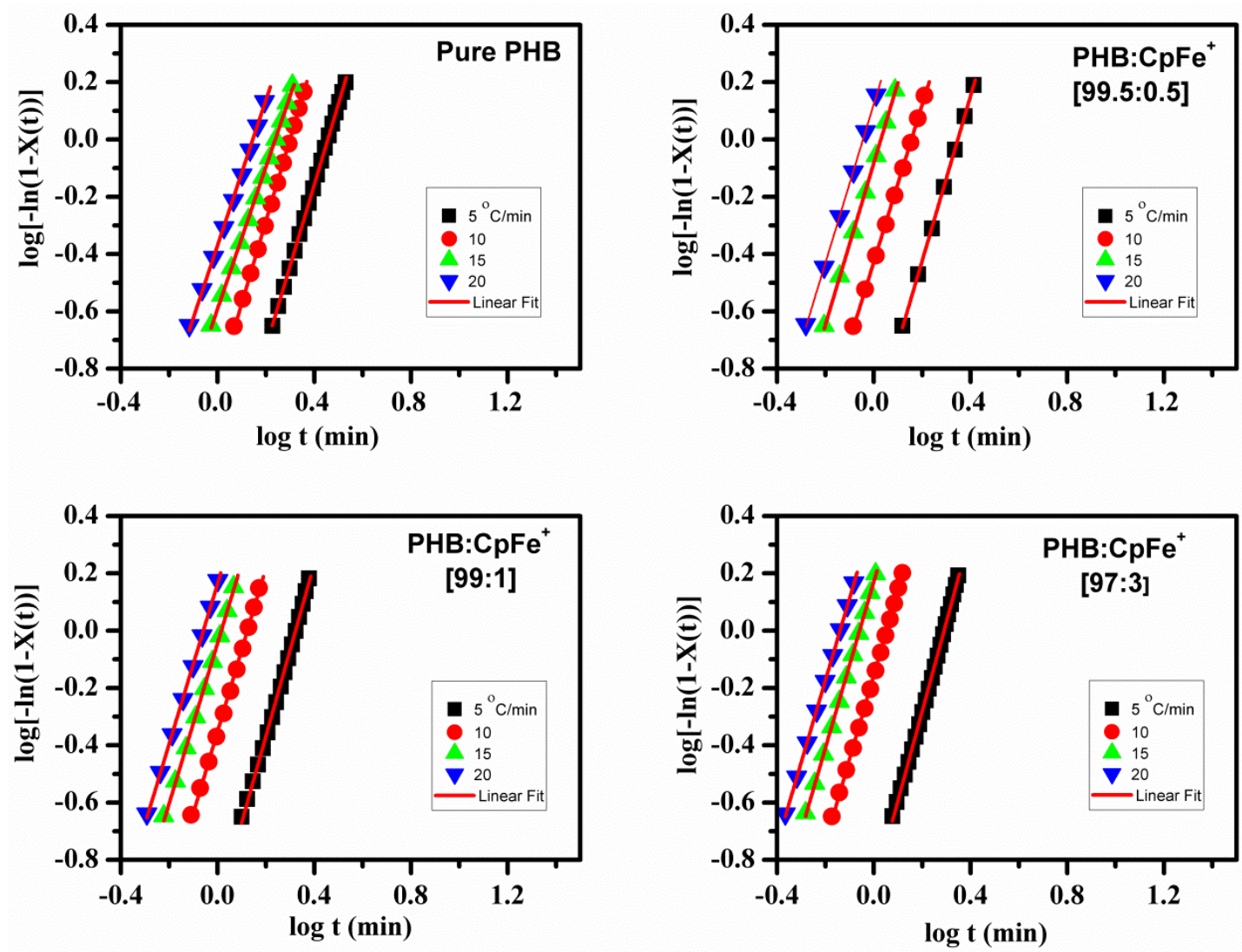

Figure 9. Typical Avrami plots of $\log \left(1-\ln (1-\mathrm{X}(\mathrm{t}))\right.$ versus $\log (\mathrm{t})$ of the pure $\mathrm{PHB}$ and $\mathrm{PHB} / \mathrm{CpFe}^{+}$ nanocomposites that non-isothermally crystallized at various cooling rates.

Table 3. Non-isothermal crystallization kinetics parameters of the pure $\mathrm{PHB}$ and $\mathrm{PHB} / \mathrm{CpFe}{ }^{+}$ nanocomposites based on the modified Avrami model.

\begin{tabular}{|c|c|c|c|c|c|c|c|c|c|c|c|c|}
\hline \multirow{2}{*}{\multicolumn{2}{|c|}{$\begin{array}{l}\text { Name of PHB } \\
\text { Samples }\end{array}$}} & $\varphi$ & $\Delta t_{i n c}$ & $T_{c}$ & $\Delta H_{c}$ & $n$ & $\log k_{t}$ & $k_{t} \times 10^{-2}$ & $K_{c}$ & $R^{2}$ & $t_{0.5}$ & $C R P \times 10^{-2}$ \\
\hline & & $\begin{array}{c}{ }^{\circ} \mathrm{C} \\
/ \mathrm{min}\end{array}$ & $\min$ & ${ }^{\circ} \mathrm{C}$ & $\mathrm{J} / \mathrm{g}$ & & & $\min ^{-1}$ & $\min ^{-1}$ & & Min & \\
\hline \multirow{16}{*}{ 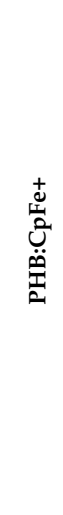 } & \multirow{4}{*}{ 100:0 } & 5 & 16.9 & 102 & 83.4 & 3 & -1.3 & 5.13 & 0.55 & 1 & 2.5 & \multirow{4}{*}{2.72} \\
\hline & & 10 & 9.14 & 91 & 72.1 & 3 & -0.86 & 13.83 & 0.81 & 1 & 1.8 & \\
\hline & & 15 & 6.29 & 83 & 67.5 & 3 & -0.59 & 25.63 & 0.91 & 1 & 1.5 & \\
\hline & & 20 & 4.83 & 76 & 65.3 & 3 & -0.37 & 42.76 & 0.95 & 1 & 1.2 & \\
\hline & \multirow{4}{*}{ 99.5:0.5 } & 5 & 15.7 & 112 & 91.5 & 3 & -0.99 & 10.06 & 0.63 & 1 & 2 & \multirow{4}{*}{6.36} \\
\hline & & 10 & 8.09 & 109 & 87.9 & 3 & -0.24 & 58.16 & 0.91 & 1 & 1.1 & \\
\hline & & 15 & 5.53 & 105 & 85.4 & 3 & 0.11 & 131.2 & 0.99 & 1 & 0.8 & \\
\hline & & 20 & 4.24 & 102 & 83.3 & 3 & 0.35 & 224.4 & 1.01 & 1 & 0.7 & \\
\hline & \multirow{4}{*}{ 99:1 } & 5 & 15.6 & 112 & 93.8 & 3 & -0.97 & 10.71 & 0.64 & 1 & 1.9 & \multirow{4}{*}{5.12} \\
\hline & & 10 & 8.07 & 107 & 87.4 & 3 & -0.35 & 44.5 & 0.92 & 1 & 1.2 & \\
\hline & & 15 & 5.51 & 104 & 85.4 & 3 & -0.04 & 90.49 & 0.99 & 1 & 0.9 & \\
\hline & & 20 & 4.21 & 101 & 83.6 & 3 & 0.16 & 145.8 & 1.02 & 1 & 0.8 & \\
\hline & \multirow{4}{*}{$97: 3$} & 5 & 15.8 & 113 & 90.9 & 3 & -0.90 & 12.49 & 0.66 & 1 & 1.8 & \multirow{4}{*}{6.5} \\
\hline & & 10 & 8.06 & 110 & 85.8 & 3 & -0.15 & 70.08 & 0.97 & 1 & 1 & \\
\hline & & 15 & 5.5 & 106 & 84 & 3 & 0.17 & 148.3 & 1.02 & 1 & 0.8 & \\
\hline & & 20 & 4.21 & 104 & 81.9 & 3 & 0.4 & 251.7 & 1.05 & 1 & 0.6 & \\
\hline
\end{tabular}

It is well known that the Avrami equation assumes that during the isothermal crystallization process, the nucleation rate remains constant. However, the nucleation rate is not constant when the PHB samples are crystallized under non-isothermal crystallization conditions [26]. Therefore, the $\mathrm{n}$ values for the non-isothermal crystallization kinetics are higher than those under the isothermal 
ones. This infers that much more complicated processes occur during the melt of non-isothermal crystallization [58]. Other possible explanations that appear in the literature are that $n$ and $k_{t}$ are two adjustable parameters [62-64]. Additionally, the $\mathrm{k}_{\mathrm{t}}$ values, at any given composition, increase by increasing the cooling rate and, at any given cooling rate, increase with the increase in the content of the $\mathrm{CpFe}^{+}$. A similar trend was detected for an inverse half-life time of crystallization, as shown in Table 3 .

Combining both the Avrami and Ozawa models was proposed by Liu [62] at a given value of relative crystallinity $X(t)$, as in the following Equation (7):

$$
\log (\mathrm{k})+\mathrm{n} \log (\mathrm{t})=\log \left(\mathrm{k}_{0}(\mathrm{~T})\right)-\mathrm{m}_{0} \log (\varphi)
$$

After rearrangement, it became Equation (8):

$$
\log (\varphi)=\log \mathrm{F}(\mathrm{T})-\mathrm{b} \log (\mathrm{t})
$$

The $\mathbf{b}$ is the ratio of the Avrami exponent $(\boldsymbol{n})$ to the Ozawa exponent (m):

$$
\begin{gathered}
\mathrm{b}=\mathrm{n} / \mathrm{m} \\
\mathrm{F}(\mathrm{T})=\left[\mathrm{k}_{\mathrm{O}}(\mathrm{T}) / \mathrm{k}\right]^{\frac{1}{\mathrm{~m}}}
\end{gathered}
$$

Figure 10 exhibits $\log (\varphi)$ as a function of $\log (t)$ at a certain relative crystallinity $(20 \%, 40 \%, 60 \%$, and $80 \%$ ) for the $\mathrm{PHB} / \mathrm{CpFe}^{+}$nanocomposites. A good linearity was achieved for all the PHB samples, as shown in Figure 10. The values of $\log \mathrm{F}(\mathrm{T})$ were determined by the intercept of the lines according to Equation (8) and are reported in Table 4. The $\mathrm{F}(\mathrm{T})$ value significantly shifted to higher values with the increase of the degree of the crystallinity. Moreover, for a given $\mathrm{X}(\mathrm{t})$, the $\mathrm{F}(\mathrm{T})$ values of the $\mathrm{PHB} / \mathrm{CpFe}{ }^{+}$ nanocomposites decreased with increase of the $\mathrm{CpFe}^{+}$content, indicating a pronounced effect of $\mathrm{CpFe}^{+}$.
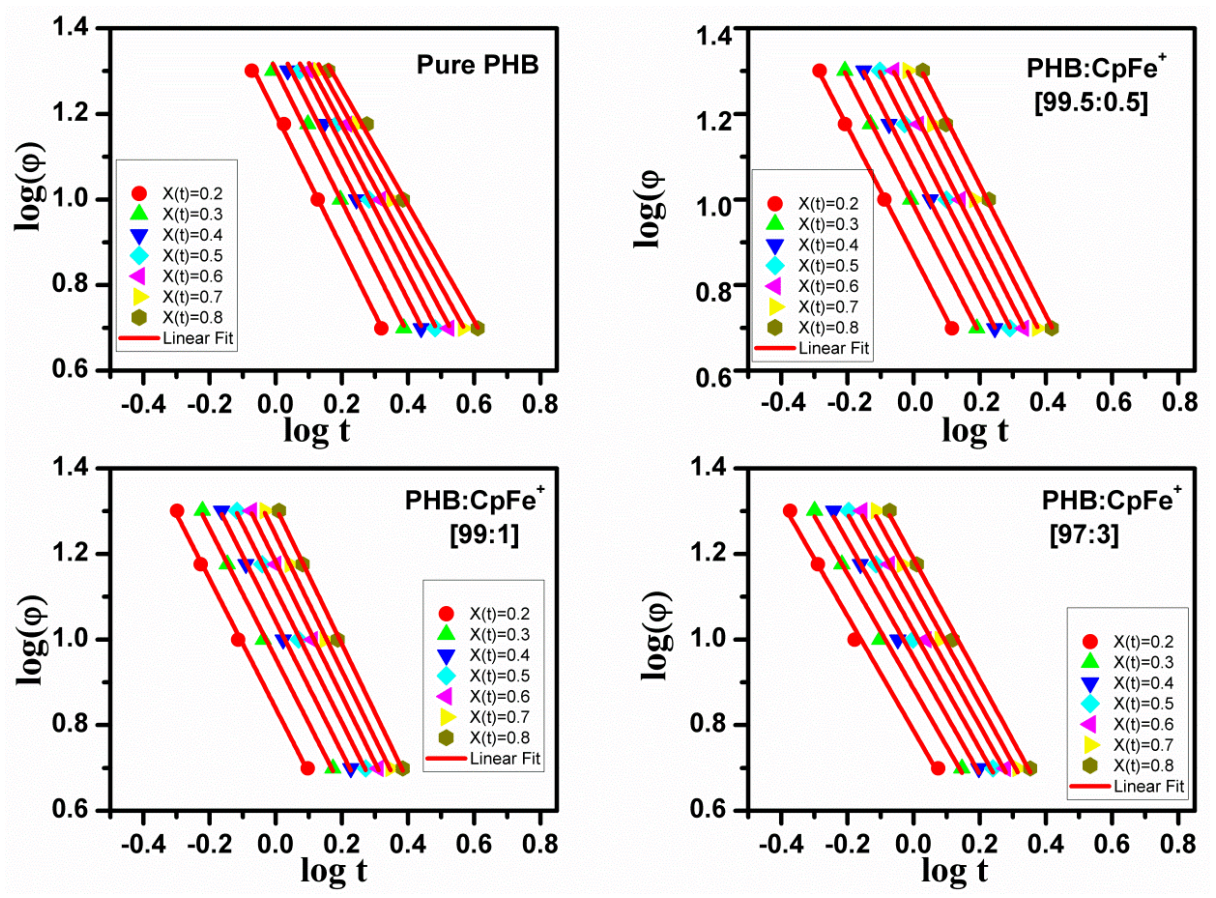

Figure 10. Plots of $\log (\varphi)$ versus $\log (\mathrm{t})$ for the pure $\mathrm{PHB}$ and $\mathrm{PHB} / \mathrm{CpFe}^{+}$nanocomposites that non-isothermally crystallized at a given $\mathrm{X}(\mathrm{t})$. 
Table 4. $\mathrm{F}(\mathrm{T})$ and $\mathrm{b}$ values by $\mathrm{MO}$ approach for pure $\mathrm{PHB}$ and $\mathrm{PHB} / \mathrm{CpFe}^{+}$nanocomposites.

\begin{tabular}{|c|c|c|c|c|c|c|}
\hline \multicolumn{2}{|c|}{ Name of PHB Samples } & \multirow{2}{*}{$\begin{array}{l}\text { Kinetics } \\
\text { Parameter }\end{array}$} & \multicolumn{4}{|c|}{$X(t)$} \\
\hline & & & 0.2 & 0.4 & 0.6 & 0.8 \\
\hline \multirow{12}{*}{ PHB:CpFe+ } & \multirow{3}{*}{ 100:0 } & $\mathbf{F}(\mathbf{T})$ & 15.83 & 23.59 & 29.10 & 33.80 \\
\hline & & b & -1.56 & -1.52 & -1.45 & -1.36 \\
\hline & & $R^{2}$ & 0.997 & 0.993 & 0.993 & 0.995 \\
\hline & \multirow{3}{*}{ 99.5:0.5 } & $\mathbf{F}(\mathbf{T})$ & 7.239 & 8.903 & 10.047 & 11.122 \\
\hline & & b & -1.496 & -1.509 & -1.522 & -1.522 \\
\hline & & $R^{2}$ & 0.999 & 0.999 & 0.999 & 0.998 \\
\hline & \multirow{3}{*}{ 99:1 } & $\mathbf{F}(\mathbf{T})$ & 6.978 & 8.669 & 9.825 & 10.889 \\
\hline & & b & -1.512 & -1.535 & -1.565 & -1.602 \\
\hline & & $R^{2}$ & 0.998 & 0.999 & 0.999 & 0.999 \\
\hline & \multirow{3}{*}{$97: 3$} & $\mathbf{F}(\mathbf{T})$ & 6.546 & 7.965 & 8.940 & 9.882 \\
\hline & & b & -1.339 & -1.362 & -1.384 & -1.414 \\
\hline & & $R^{2}$ & 0.993 & 0.994 & 0.995 & 0.995 \\
\hline
\end{tabular}

\subsection{An Effective Activation Energy of Non-Isothermal Crystallization}

Several models in the literature have been proposed to determine the effective activation energy [65]. The isoconversional model is the most applicable model to evaluate the activation energy under a variety of heating and/or cooling rates [66]. The main assumption of this model is that at a constant relative crystallinity, the reaction rate is only a function of the temperature, as follows in Equation (9):

$$
\left[\frac{d \text { the } \ln (\mathrm{X}(\mathrm{t}) / \mathrm{t})}{\mathrm{dT}^{-1}}\right]_{\mathrm{x}(\mathrm{t})}=-\frac{\mathrm{E}_{\mathrm{X}(\mathrm{t})}}{\mathrm{R}}
$$

The subscript $X(t)$ refers to the values corresponding to a given relative crystallinity. Plotting $\mathrm{d} \ln (\mathrm{X}(\mathrm{t}) / \mathrm{t})$ versus $\mathrm{dT}^{-1}$ at different cooling rates at a given $\mathrm{X}(\mathrm{t})$ gives a straight line with regression around 0.97 . The dependence of the effective activation energy on the relative crystallinity is shown in Figure 11a. It can be discerned that the effective activation energy has a negative value and increases (shifts to a more positive value) with the increase of the relative degree of the crystallinity for the pure PHB and its nanocomposites, Figure 11. This trend was reported previously in the literature.
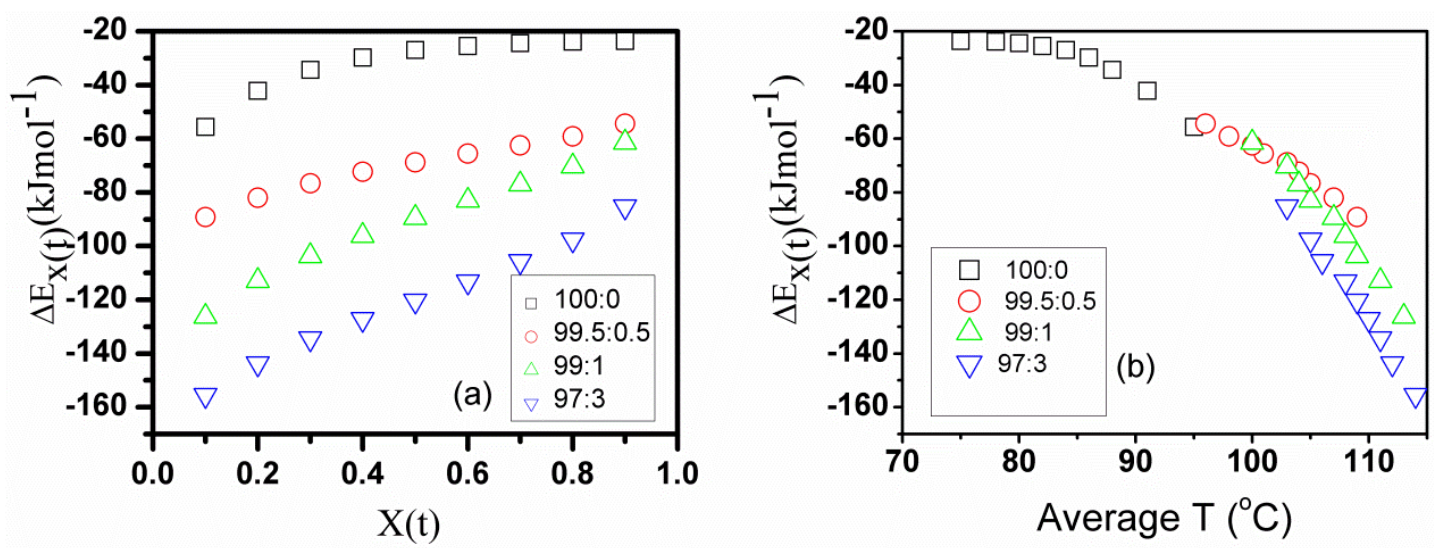

Figure 11. Dependence of the effective activation energy of the pure $\mathrm{PHB}$ and $\mathrm{PHB} / \mathrm{CpFe}^{+}$ nanocomposites on (a) $\mathrm{X}(\mathrm{t})$ and $(\mathbf{b})$ average temperature.

Vyazovkin [65] stated that the experimental activation energy takes greater negative values at low extents of conversion that correspond to temperatures closer to the melting point. Negative values of the effective activation energy mean that the crystallization rate decreases with increasing temperatures (the anti-Arrhenius process) [67]. Our results showed that the effective activation energy of the pure 
PHB increased slightly with the extent of the crystallization from -38 to $-41 \mathrm{~kJ} \mathrm{~mol}^{-1}$. A similar trend was observed for pure PHB in [68].

In general, the effective activation energy of the pure PHB in its nanocomposites is much lower than that of the pure form. The lowest activation energy value was obtained at the $\mathrm{PHB} / \mathrm{CpFe}^{+}$ratio of 97:3. The reduction of the effective activation energy values in the nanocomposites has been attributed to the occurrence of the heterogeneous nucleation mechanism with the organometallic moieties, which can be distinguished in the polarized optical microscopy images, Figure 1.

The activation energy is closely related to the transport of the macromolecular chains to the growing surface and nucleation steps [65]. Figure 11b elucidates the dependence of the effective activation energy on the average temperature. The average temperature can be estimated by an average crystallization temperature related to a given relative crystallinity. As noticed from Figure 11b, the effective activation energy exhibited more negative values at higher average temperatures, which is consistent with the previous report [65]. The combination of the $\mathrm{CpFe}^{+}$moieties with the PHB prompted the formation of more nuclei at high crystallization temperatures, which, consequently, has the lowest effective activation energy.

\subsection{Thermal Gravimetric Analysis}

The thermal stability of the PHB in the nanocomposites was determined using TGA and DTGA, as shown in Figure 12, and summarized in Table 5. The maximum degradation temperature of the pure PHB was achieved at $288^{\circ} \mathrm{C}$. Moreover, the $\mathrm{CpFe}^{+}$complex was degraded by two steps. The initial degradation step corresponded to the cleavage of the arene ring, while the second step was comprised of the decomposition of the organic moieties. The maxima degradation temperatures of the $\mathrm{CpFe}^{+}$for the first and second steps were $243^{\circ} \mathrm{C}$ and $410{ }^{\circ} \mathrm{C}$, respectively. On the other hand, the $\mathrm{PHB} / \mathrm{CpFe}{ }^{+}$ nanocomposites decomposed through a one-step degradation mechanism, which was found to be higher than that of the pure PHB by $10^{\circ} \mathrm{C}$. Furthermore, the thermal degradation temperatures of the $\mathrm{PHB} / \mathrm{CpFe}^{+}$nanocomposites were almost constant and were independent of their ratios, as shown in Table 5 This result implies that the introduction of the $\mathrm{CpFe}^{+}$complex improved the thermal stability of the PHB due to the strong chemical interaction, as described previously in the text.
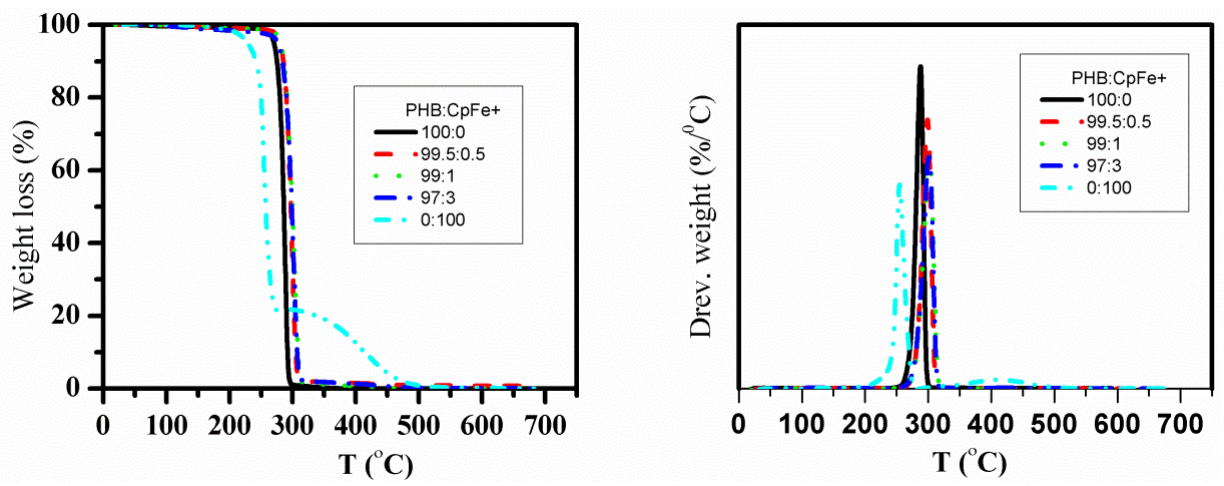

Figure 12. Thermogravimetry and differential thermogravimetry curves of the pure PHB and $\mathrm{PHB} / \mathrm{CpFe}^{+}$nanocomposites.

Table 5. Thermal stability parameters of $\mathrm{PHB}$ and $\mathrm{PHB} / \mathrm{CpFe}^{+}$nanocomposites.

\begin{tabular}{ccccc}
\hline \multirow{2}{*}{ Name of PHB Samples } & \multicolumn{3}{c}{ PHB Phase } \\
\cline { 3 - 5 } & $\mathbf{1 0 0 : 0}$ & $\boldsymbol{T}_{\text {onset }}$ & $\boldsymbol{T}_{\text {max }}$ & $\boldsymbol{T}_{\text {end }}$ \\
\hline $\mathbf{9 9 . 5 : 0 . 5}$ & 280 & 288 & 293 \\
PHB:CpFe+ & $\mathbf{9 9 : 1}$ & 287 & 297 & 303 \\
& $\mathbf{9 7 : 3}$ & 286 & 297 & 303 \\
& $\mathbf{9 0 : 1 0}$ & 287 & 298 & 305 \\
& $\mathbf{0 : 1 0 0}$ & 200 & 300 & 306 \\
& 354 & 243 & 255 \\
& & & 410 & 455 \\
\hline
\end{tabular}




\section{Materials and Methods}

The pure bacterial Poly(3-hydroxybutyrate) (PHB), in the form of white powder, was kindly provided by Dr. Haenggi, Biomer Company, Germany. The PHB was more than $98 \%$, the content of the polyhydroxyvalerate (PHV) was less than $1 \%$, and the remaining cell membrane and membrane lipids were ca. $1 \%$. The weight average molecular weight was about $600,000 \mathrm{~g} / \mathrm{mol}$. The melt flow rate (MFR) at $180{ }^{\circ} \mathrm{C}$ with $2.16 \mathrm{~kg}$ was $10 \mathrm{~g} / 10 \mathrm{~min}$; methylene chloride $(99.9 \%)$ was supplied from Sigma Aldrich, Germany. No further purification was performed on the materials. The $\eta^{6}$-arene- $\eta^{5}$-cyclopentadienyliron complex $\left(\mathrm{CpFe}^{+}\right)$was prepared in accordance with the previously reported methodology [69]. The structural identity of the iron complex was confirmed using spectroscopic analysis. For example, the ${ }^{1} \mathrm{H}$ NMR spectrum exhibited two singlet resonances at 5.6 and $6.9 \mathrm{ppm}$, which corresponded to the equivalent cyclopentadienyl protons and the complexed aromatic arene protons, respectively. In the meantime, the FTIR spectrum displayed an out of plan bending peak, corresponding to the complexed arene $\mathrm{C}-\mathrm{H}$ at $816 \mathrm{~cm}^{-1}$, while their stretching bands were observed at 3097,469 , and $553 \mathrm{~cm}^{-1}$. Furthermore, the frequencies of the complexed cyclopentadienyl $\mathrm{C}-\mathrm{H}$ stretching band resonated in the range of $2901-2987 \mathrm{~cm}^{-1}$.

\subsection{Preparation of Blends}

$\mathrm{PHB} / \mathrm{CpFe}^{+}$composites with different weight ratios were prepared through a casting film technique using methylene chloride as a solvent. For each film, approximately $2.00 \mathrm{~g}$ of the total sample were mixed and dissolved in $50 \mathrm{~mL}$ of methylene chloride with stirring at $40^{\circ} \mathrm{C}$ for $45 \mathrm{~min}$ to ensure the complete dissolution of both components. After that, the solution was kept at room temperature for $120 \mathrm{~min}$ and then casted onto a glass Petri dish at room temperature to slowly evaporate the solvent and to form homogenously a film. The cast film samples were molten between hot melt press at $200{ }^{\circ} \mathrm{C}$ for $2 \mathrm{~min}$. The thickness of the specimen was measured using a digital micrometer and was found to be $0.67 \pm 0.01 \mathrm{~mm}$.

\subsection{Characterization}

The spherulitic morphologies of the samples were examined on an Olympus CX31 polarizing optical microscope (POM) equipped with a digital camera system, E330. Samples weighing 3-5 mg were melted on glass slips with cover slips to form $20-50 \mathrm{~mm}$ thick films. Each specimen was melted at $200{ }^{\circ} \mathrm{C}$ for $2 \mathrm{~min}$ on a hot stage and then was cooled to the selected crystallization temperature of $100{ }^{\circ} \mathrm{C}$. The polarized optical micrographs were recorded after $1 \mathrm{~h}$ annealing at the crystallization temperature of $100{ }^{\circ} \mathrm{C}$.

Wide angle $X$-ray diffraction, $X R D$, measurements were conducted by a Shimadzu XRD-6100 $X$-ray diffractometer with $\mathrm{Cu}-\mathrm{K} \alpha$ radiation $(\lambda=0.154 \mathrm{~nm}, 40 \mathrm{kV}$, and $30 \mathrm{~mA})$. The $\mathrm{X}$-ray diffraction patterns were carried out at ambient temperature in the $2 \theta$ range of $10-80^{\circ}$ with a scanning step and rate of $0.02^{\circ}$ and $2^{\circ} / \mathrm{min}$, respectively.

The transition temperatures of the samples were detected using a differential scanning colorimeter DSC-Q2000 from TA instruments Co. with a Universal Analysis 2000. The DSC temperature and heat flow were calibrated with indium according to the methodology mentioned previously [70]. All the experiments were carried out under a nitrogen atmosphere $(30 \mathrm{~mL} / \mathrm{min})$. The samples were first heated from $-50{ }^{\circ} \mathrm{C}$ to $200{ }^{\circ} \mathrm{C}$ to eliminate their thermal history and enhance their thermal contact at a heating rate of $20^{\circ} \mathrm{C}$; subsequently, they were cooled to $-50{ }^{\circ} \mathrm{C}$ at a rate of $20^{\circ} \mathrm{C} / \mathrm{min}$ and then were reheated to $200{ }^{\circ} \mathrm{C}$ at a rate of $20^{\circ} \mathrm{C} / \mathrm{min}$ (second heating rate). The data of the first heating run are not discussed here. The crystallization temperature $\left(\mathrm{T}_{\mathrm{C}}\right)$ and its enthalpy $\left(\Delta H_{C}\right)$ were detected through the cooling curve. The glass transition temperature $\left(T_{g}\right)$ was estimated as the midpoint of the specific heat capacity step from the second heating run. The cold crystallization temperature $\left(T_{C C}\right)$, the melting temperature $\left(T_{m}\right)$, and their enthalpies $\left(\Delta H_{C C}\right.$ and $\left.\Delta H_{m}\right)$ were determined from 
the respective exothermal and endothermal processes in the DSC second heating run. The overall crystallinity $\left(\chi_{c}\right)$ of the PHB in the blend was calculated with Equation (1).

$\Delta H_{m}$ and $\Delta H c c$ are the experimental melting and cold crystallization enthalpy, respectively. $w$ is the weight fraction of the PHB in the blend, and $\Delta H_{m}^{\circ}$ is the melting enthalpy of $100 \%$ crystalline of $\mathrm{PHB}$, which is taken as $146 \mathrm{~J} / \mathrm{g}$ [15].

For the study of the non-isothermal crystallization, the samples were heated to $200{ }^{\circ} \mathrm{C}$ rapidly and held for $2 \mathrm{~min}$, and then, the DSC curves were recorded during cooling at various cooling rates $\left(5,10,15\right.$, and $\left.20^{\circ} \mathrm{C} / \mathrm{min}\right)$. The crystallization temperature during cooling $\left(\mathrm{T}_{\mathrm{C}}\right)$ and the enthalpy of crystallization on cooling $\left(\Delta H_{C}\right)$ were determined from these scans.

Thermogravimetric analysis, TGA, measurements were conducted using a TA Instruments SDT-Q600 thermal analyzer at a heating rate of $20{ }^{\circ} \mathrm{C} / \mathrm{min}$ under a nitrogen atmosphere with a purge of $20 \mathrm{~mL} / \mathrm{min}$ from 20 to $700{ }^{\circ} \mathrm{C}$. The sample mass was about $2-5 \mathrm{mg}$, and it was placed in an alumina crucible.

\section{Conclusions}

This study represents the first example of employing the cationic cyclopentadienyliron $\left(\mathrm{CpFe}^{+}\right)$ complex as a nucleating agent for the enhancement of the properties of the PHB biodegradable polymer. The influence of this metallic complex on the crystallization behavior of the bacterial PHB has been studied profoundly. The new nucleating agent displayed an excellent distribution into the polymer matrix without any sign of agglomeration. Meanwhile, the blending process was assisted by the coordination of the $\mathrm{CpFe}^{+}$with the ester carbonyl of the polymer chains. Furthermore, the incorporation of the $\mathrm{CpFe}^{+}$had a multitude of outcomes. For instance, merging the cationic organoiron complex into the PHB materials shifted the melt crystallization temperature $26^{\circ} \mathrm{C}$ higher than that of its pure analogue. It also promptly increased the crystallization rate of the bacterial PHB by $87 \%$ with no influence on the polymeric crystal lattice. The isothermal and non-isothermal crystallization behaviors of the polymer have been elucidated using the Avrami model, the modified Avrami model, and the combination Avrami and Ozawa model. In addition, the presence of the cationic nucleating agent lowered the effective activation energy of the PHB, owing to its heterogeneous nucleation mechanism with the polymer matrix, which is an indication of a faster crystallization rate that leads to a shortened production cycle time for the polymer processing techniques. All these results signify that the $\mathrm{CpFe}^{+}$is a superior novel nucleating agent and that the complex has been deemed to be a good candidate for high-temperature polymer processing techniques and commodity applications.

Author Contributions: S.H.E.-T. and R.M.O. conceived of and designed the experiments; S.H.E.-T., A.O.A.-A., O.A., and R.M.O. performed the experiments; S.H.E.-T. and R.M.O. analyzed the data and wrote the paper. All the authors discussed the results and commented on the final manuscript.

Acknowledgments: The authors gratefully acknowledge the Deanship of Scientific Research, Taibah University for the support of this research work with project no. 7023/36. The authors express their gratitude to Nessrin Kattan for her assistance with the XRD and SEM analysis, and finally, the authors also acknowledge Malak T. Mahmoud for her editing assistance.

Conflicts of Interest: The authors declare no conflicts of interest.

\section{References}

1. Bugnicourt, E.; Cinelli, P.; Lazzeri, A.; Alvarez, V. Polyhydroxyalkanoate (PHA): Review of synthesis, characteristics, processing and potential applications in packaging. Express. Polym. Lett. 2014, 8, 791-808. [CrossRef]

2. Gumel, A.M.; Annuar, M.S.M.; Chisti, Y. Recent Advances in the Production, Recovery and Applications of Polyhydroxyalkanoates. J. Polym. Environ. 2013, 21, 580-605. [CrossRef]

3. Vilela, C.; Sousa, A.F.; Fonseca, A.C.; Serra, A.C.; Coelho, J.F.J.; Freire, C.S.R.; Silvestre, A.J.D. The quest for sustainable polyesters-Insights into the future. Polym. Chem. 2014, 5, 3119-3141. [CrossRef]

4. Lagarón, J.M.; López-Rubio, A.; José Fabra, M. Bio-based packaging. J. Appl. Polym. Sci. 2016, 133. [CrossRef] 
5. Pan, Y.; Farmahini-Farahani, M.; O’Hearn, P.; Xiao, H.; Ocampo, H. An overview of bio-based polymers for packaging materials. J. Bioresour. Bioprod. 2016, 1, 106-113.

6. Reddy, M.M.; Vivekanandhan, S.; Misra, M.; Bhatia, S.K.; Mohanty, A.K. Biobased plastics and bionanocomposites: Current status and future opportunities. Prog. Polym. Sci. 2013, 38, 1653-1689. [CrossRef]

7. Nair, L.S.; Laurencin, C.T. Biodegradable polymers as biomaterials. Prog. Polym. Sci. 2007, 32, $762-798$. [CrossRef]

8. Chanprateep, S. Current trends in biodegradable polyhydroxyalkanoates. J. Biosci. Bioeng. 2010, 110, 621-632. [CrossRef] [PubMed]

9. Shah, A.A.; Kato, S.; Shintani, N.; Kamini, N.R.; Nakajima-Kambe, T. Microbial degradation of aliphatic and aliphatic-aromatic co-polyesters. Appl. Microbiol. Biotechnol. 2014, 98, 3437-3447. [CrossRef] [PubMed]

10. Kushwah, B.S.; Kushwah, A.V.S.; Singh, V. Towards understanding polyhydroxyalkanoates and their use. J. Polym. Res. 2016, 23, 153. [CrossRef]

11. Jiang, L.; Zhang, J. Biodegradable Polymers and Polymer Blends. In Handbook of Biopolymers and Biodegradable Plastics; Elsevier: Oxford, UK; William Andrew: Waltham, MA, USA, 2013; pp. 109-128. ISBN 9781455728343.

12. Jayanth, D.; Kumar, P.S.; Nayak, G.C.; Kumar, J.S.; Pal, S.K.; Rajasekar, R. A Review on Biodegradable Polymeric Materials Striving Towards the Attainment of Green Environment. J. Polym. Environ. 2018, 26, 838-865. [CrossRef]

13. Ha, C.S.; Cho, W.J. Miscibility, properties, and biodegradability of microbial polyester containing blends. Prog. Polym. Sci. 2002, 27, 759-809. [CrossRef]

14. Barham, P.J.; Keller, A.; Otun, E.L.; Holmes, P.A. Crystallization and morphology of a bacterial thermoplastic: Poly-3-hydroxybutyrate. J. Mater. Sci. 1984, 19, 2781-2794. [CrossRef]

15. Mitomo, H.; Barham, P.J.; Keller, A. Crystallization and Morphology of Poly( $\beta$-hydroxybutyrate) and Its Copolymer. Polym. J. 1987, 19, 1241-1253. [CrossRef]

16. Tanadchangsaeng, N. Structure, chemomechanical properties and degradability of polyhydroxyalkanoates: A review. Bull. Health Sci. Technol. 2014, 12, 9-21.

17. Gurunathan, T.; Mohanty, S.; Nayak, S.K. A review of the recent developments in biocomposites based on natural fibres and their application perspectives. Compos. Part. A Appl. Sci. Manuf. 2015, 77, 1-25. [CrossRef]

18. Organ, S.J.; Barham, P.J. Nucleation of poly(hydroxy butyrate) by epitaxy on nitrogen-containing compounds. J. Mater. Sci. 1992, 27, 3239-3242. [CrossRef]

19. Huang, Y.; Paul, D.R. Effect of MolecularWeight and Temperature on Physical Aging of ThinGlassy Poly(2,6-dimethyl-1,4-phenylene oxide) Films. J. Polym. Sci. Part B Polym. Phys. 2007, 45, 1390-1398. [CrossRef]

20. Puente, J.A.S.; Esposito, A.; Chivrac, F.; Dargent, E. Effect of boron nitride as a nucleating agent on the crystallization of bacterial poly(3-hydroxybutyrate). J. Appl. Polym. Sci. 2013, 128, 2586-2594. [CrossRef]

21. Öner, M.; Çöl, A.A.; Pochat-Bohatier, C.; Bechelany, M. Effect of incorporation of boron nitride nanoparticles on the oxygen barrier and thermal properties of poly(3-hydroxybutyrate-co-hydroxyvalerate). RSC Adv. 2016, 6, 90973-90981. [CrossRef]

22. Vandewijngaarden, J.; Murariu, M.; Dubois, P.; Carleer, R.; Yperman, J.; D’Haen, J.; Peeters, R.; Buntinx, M. Effect of ultrafine talc on crystallization and end-use properties of poly(3-hydroxybutyrate-co-3-hydroxyhexanoate). J. Appl. Polym. Sci. 2016, 133, 1-10. [CrossRef]

23. Kai, W.; He, Y.; Inoue, Y. Fast crystallization of poly(3-hydroxybutyrate) and poly(3-hydroxybutyrate-co-3hydroxyvalerate) with talc and boron nitride as nucleating agents. Polym. Int. 2005, 54, 780-789. [CrossRef]

24. Pan, P.; Shan, G.; Bao, Y.; Weng, Z. Crystallization kinetics of bacterial poly(3-hydroxylbutyrate) copolyesters with cyanuric acid as a nucleating agent. J. Appl. Polym. Sci. 2013, 129, 1374-1382. [CrossRef]

25. He, Y.; Inoue, Y. Effect of $\alpha$-cyclodextrin on the crystallization of poly(3-hydroxybutyrate). J. Polym. Sci. Part. B Polym. Phys. 2004, 42, 3461-3469. [CrossRef]

26. Weihua, K.; He, Y.; Asakawa, N.; Inoue, Y. Effect of lignin particles as a nucleating agent on crystallization of poly(3-hydroxybutyrate). J. Appl. Polym. Sci. 2004, 94, 2466-2474. [CrossRef]

27. Jing, X.; Qiu, Z. Effect of Low Thermally Reduced Graphene Loadings on the Crystallization Kinetics and Morphology of Biodegradable Poly(3-hydroxybutyrate). Ind. Eng. Chem. Res. 2012, 51, 13686-13691. [CrossRef]

28. Shan, G.-F.; Gong, X.; Chen, W.-P.; Chen, L.; Zhu, M.-F. Effect of multi-walled carbon nanotubes on crystallization behavior of poly(3-hydroxybutyrate-co-3-hydroxyvalerate). Colloid Polym. Sci. 2011, 289, 1005-1014. [CrossRef] 
29. Lai, M.; Li, J.; Yang, J.; Liu, J.; Tong, X.; Cheng, H. The morphology and thermal properties of multi-walled carbon nanotube and poly(hydroxybutyrate-co-hydroxyvalerate) composite. Polym. Int. 2004, 53, 1479-1484. [CrossRef]

30. Jaques, N.G.; Silva, I.D.D.S.; Barbosa Neto, M.D.C.; Diniz, R.K.M.; Wellen, R.M.R.; Canedo, E.L. Comparative study of the effect of $\mathrm{TiO} 2$ and $\mathrm{ZnO}$ on the crystallization of PHB. Matéria 2017, 22. [CrossRef]

31. Montagna, L.S.; Montanheiro, T.L.D.A.; Machado, J.P.B.; Passador, F.R.; Lemes, A.P.; Rezende, M.C. Effect of Graphite Nanosheets on Properties of Poly(3-hydroxybutyrate-co-3-hydroxyvalerate). Int. J. Polym. Sci. 2017, 2017, 1-9. [CrossRef]

32. Naffakh, M.; Marco, C.; Ellis, G.; Cohen, S.R.; Laikhtman, A.; Rapoport, L.; Zak, A. Novel poly(3-hydroxybutyrate) nanocomposites containing WS2 inorganic nanotubes with improved thermal, mechanical and tribological properties. Mater. Chem. Phys. 2014, 147, 273-284. [CrossRef]

33. Mofokeng, J.P.; Luyt, A.S. Morphology and thermal degradation studies of melt-mixed poly(hydroxybutyrate-co-valerate) (PHBV)/poly( $\varepsilon$-caprolactone) (PCL) biodegradable polymer blend nanocomposites with TiO2 as filler. J. Mater. Sci. 2015, 50, 3812-3824. [CrossRef]

34. Bekat, T.; Öner, M. Effects of surface modification and ultrasonic agitation on the properties of PHBV/ZnO nanocomposites. Pure Appl. Chem. 2016, 88, 1027-1035. [CrossRef]

35. Gahleitner, M.; Wolfschwenger, J. Polymer Crystal Nucleating Agents. In Encyclopedia of Materials: Science and Technology; Elsevier: Oxford, UK, 2001; pp. 7239-7244. ISBN 978-0-08-043152-9.

36. Martínez-Sanz, M.; Villano, M.; Oliveira, C.; Albuquerque, M.G.E.; Majone, M.; Reis, M.; Lopez-Rubio, A.; Lagaron, J.M. Characterization of polyhydroxyalkanoates synthesized from microbial mixed cultures and of their nanobiocomposites with bacterial cellulose nanowhiskers. New Biotechnol. 2014, 31, 364-376. [CrossRef] [PubMed]

37. Yeo, S.Y.; Tan, W.L.; Abu Bakar, M.; Ismail, J. Silver sulfide/poly(3-hydroxybutyrate) nanocomposites: Thermal stability and kinetic analysis of thermal degradation. Polym. Degrad. STable 2010, 95, 1299-1304. [CrossRef]

38. Duangphet, S.; Szegda, D.; Tarverdi, K.; Song, J. Effect of Calcium Carbonate on Crystallization Behavior and Morphology of Poly(3-Hydroxybutyrate-co-3-Hydroxyvalerate). Key Eng. Mater. 2017, 751, $242-251$. [CrossRef]

39. Duan, B.; Wang, M.; Zhou, W.-Y.; Cheung, W.-L. Nonisothermal melt-crystallization behavior of calcium phosphate/poly(3-hydroxybutyrate-co-3-hydroxyvalerate) nanocomposite microspheres. Polym. Eng. Sci. 2011, 51, 1580-1591. [CrossRef]

40. Kaynak, C.; Erdogan, A.R. Mechanical and thermal properties of polylactide/talc microcomposites: Before and after accelerated weathering. Polym. Adv. Technol. 2016, 27, 812-822. [CrossRef]

41. De O. Patrício, P.S.; Pereira, F.V.; dos Santos, M.C.; de Souza, P.P.; Roa, J.P.B.; Orefice, R.L. Increasing the elongation at break of polyhydroxybutyrate biopolymer: Effect of cellulose nanowhiskers on mechanical and thermal properties. J. Appl. Polym. Sci. 2013, 127, 3613-3621. [CrossRef]

42. Malmir, S.; Montero, B.; Rico, M.; Barral, L.; Bouza, R. Morphology, thermal and barrier properties of biodegradable films of poly (3-hydroxybutyrate-co-3-hydroxyvalerate) containing cellulose nanocrystals. Compos. Part A Appl. Sci. Manuf. 2017, 93, 41-48. [CrossRef]

43. Srithep, Y.; Ellingham, T.; Peng, J.; Sabo, R.; Clemons, C.; Turng, L.-S.; Pilla, S. Melt compounding of poly (3-hydroxybutyrate-co-3-hydroxyvalerate)/nanofibrillated cellulose nanocomposites. Polym. Degrad. STable 2013, 98, 1439-1449. [CrossRef]

44. Frone, A.N.; Berlioz, S.; Chailan, J.-F.; Panaitescu, D.M. Morphology and thermal properties of PLA-cellulose nanofibers composites. Carbohydr. Polym. 2013, 91, 377-384. [CrossRef] [PubMed]

45. Öner, M.; Ilhan, B. Fabrication of poly(3-hydroxybutyrate-co-3-hydroxyvalerate) biocomposites with reinforcement by hydroxyapatite using extrusion processing. Mater. Sci. Eng. C 2016, 65, 19-26. [CrossRef] [PubMed]

46. Joraid, A.A.; Okasha, R.M.; Rock, C.L.; Abd-El-Aziz, A.S. A Nonisothermal Study of Organoiron Poly(alkynyl methacrylate) Coordinated to Dicobalt Hexacarbonyl Using Advanced Kinetics Modelling. J. Inorg. Organomet. Polym. Mater. 2014, 24, 121-127. [CrossRef]

47. Abd-El-Aziz, A.S.; May, L.J.; Hurd, J.A.; Okasha, R.M. First ring-opening metathesis polymerization of norbornenes containing cationic iron moieties. J. Polym. Sci. Part A Polym. Chem. 2001, 39, 2716-2722. [CrossRef] 
48. Abd-El-Aziz, A.S.; Todd, E.K.; Epp, K.M. Synthesis and Characterization of Novel Organoiron Polymers. J. Inorg. Organomet. Polym. 1998, 8, 127-133. [CrossRef]

49. Abd-El-Aziz, A.S.; Okasha, R.M.; Shipman, P.O.; Afifi, T.H. Neutral and cationic cyclopentadienyliron macromolecules containing arylazo chromophores. Macromol. Rapid Commun. 2004, 25, 1497-1503. [CrossRef]

50. Okasha, R.M. Proton Sensing Color Changing Organoiron and Organic Macromolecules. J. Inorg. Organomet. Polym. Mater. 2015, 25, 354-366. [CrossRef]

51. Abd-El-Aziz, A.S.; Okasha, R.M.; Afifi, T.H.; Todd, E.K. A new class of cationic organoiron polynorbornenes containing azo dyes. Macromol. Chem. Phys. 2003, 204, 555-563. [CrossRef]

52. Abd-El-Aziz, A.S.; Schriemer, D.C.; Denus, C.R. De Bis(cyclopentadienyliron)arene Complexes: A New Route to the Synthesis and Functionalization of Polyaromatic Ethers. Organometallics 1994, 13, 374-384. [CrossRef]

53. Abd-El-Aziz, A.S.; De Denus, C.R.; Zaworotko, M.J.; MacGillivray, L.R. Controlled design of oligomeric ethers with pendant cyclopentadienyliron moieties. J. Chem. Soc. Dalton Trans. 1995, 3375-3393. [CrossRef]

54. Sato, H.; Ando, Y.; Mitomo, H.; Ozaki, Y. Infrared Spectroscopy and X-ray Diffraction Studies of Thermal Behavior and Lamella Structures of Poly(3-hydroxybutyrate-co-3-hydroxyvalerate) (P(HB-co-HV)) with PHB-Type Crystal Structure and PHV-Type Crystal Structure. Macromolecules 2011, 44, 2829-2837. [CrossRef]

55. Reusch, R. Biogenesis of Ion Channels. J. Biochem. Biophys. 2014, 24, 1-24. [CrossRef]

56. Sato, H.; Nakamura, M.; Padermshoke, A.; Yamaguchi, H.; Terauchi, H.; Ekgasit, S.; Noda, I.; Ozaki, Y. Thermal Behavior and Molecular Interaction of Poly(3-hydroxybutyrate-co-3-hydroxyhexanoate) Studied by Wide-Angle X-ray Diffraction. Macromolecules 2004, 37, 3763-3769. [CrossRef]

57. Scalioni, L.V.; Gutiérrez, M.C.; Felisberti, M.I. Green composites of poly(3-hydroxybutyrate) and curaua fibers: Morphology and physical, thermal, and mechanical properties. J. Appl. Polym. Sci. 2017, 134, 44676. [CrossRef]

58. Di Lorenzo, M.L.; Silvestre, C. Non-isothermal crystallization of polymers. Prog. Polym. Sci. 1999, 24, 917-950. [CrossRef]

59. Mansour, A.A.; Saad, G.R.; Hamed, A.H., II. Dielectric investigation of cold crystallization of poly(3hydroxybutyrate) and poly(3-hydroxybutyrate-co-3-hydroxyvalerate). Polymer 1999, 40, 5377-5391. [CrossRef]

60. Avrami, M. Kinetics of Phase Change. II Transformation-Time Relations for Random Distribution of Nuclei. J. Chem. Phys. 1940, 8, 212-224. [CrossRef]

61. Ozawa, T. Kinetics of non-isothermal crystallization. Polymer 1971, 12, 150-158. [CrossRef]

62. Liu, T.; Mo, Z.; Wang, S.; Zhang, H. Nonisothermal melt and cold crystallization kinetics of poly(aryl ether ether ketone ketone). Polym. Eng. Sci. 1997, 37, 568-575. [CrossRef]

63. Jeziorny, A. Parameters characterizing the kinetics of the non-isothermal crystallization of poly(ethylene terephthalate) determined by d.s.c. Polymer 1978, 19, 1142-1144. [CrossRef]

64. Hsu, S.F.; Wu, T.M.; Liao, C.S. Nonisothermal crystallization behavior and crystalline structure of poly(3-hydroxybutyrate)/layered double hydroxide nanocomposites. J. Polym. Sci. Part. B Polym. Phys. 2007, 45, 995-1002. [CrossRef]

65. Vyazovkin, S. Isoconversional Kinetics of Polymers: The Decade Past. Macromol. Rapid Commun. 2017, 38, 1600615. [CrossRef] [PubMed]

66. Friedman, H.L. Kinetics of thermal degradation of char-forming plastics from thermogravimetry. Application to a phenolic plastic. J. Polym. Sci. Part C Polym. Symp. 2007, 6, 183-195. [CrossRef]

67. Vyazovkin, S. A time to search: Finding the meaning of variable activation energy. Phys. Chem. Chem. Phys. 2016, 18, 18643-18656. [CrossRef] [PubMed]

68. De Lima Souza, J.; Kobelnik, M.; Ribeiro, C.A.; Capela, J.M.V.; Crespi, M.S. Kinetic study of crystallization of PHB in presence of hydroxy acids. J. Therm. Anal. Calorim. 2009, 97, 525-528. [CrossRef] 
69. Nesmeyanov, A.N.; Vol'kenau, N.A.; Bolesova, I.N. The interaction of ferrocene and its derivatives with aromatic compounds. Tetrahedron Lett. 1963, 4, 1725-1729. [CrossRef]

70. Höhne, G.W.H.; Hemminger, W.F.; Flammersheim, H.-J. Calibration of Differential Scanning Calorimeters. In Differential Scanning Calorimetry; Springer: Berlin/Heidelberg, Germany, 2003; pp. 65-114.

Sample Availability: Samples of the compounds are available from the authors.

(C) 2018 by the authors. Licensee MDPI, Basel, Switzerland. This article is an open access article distributed under the terms and conditions of the Creative Commons Attribution (CC BY) license (http://creativecommons.org/licenses/by/4.0/). 